FSM IIImî Araştırmalar Insan ve Toplum Bilimleri Dergisi

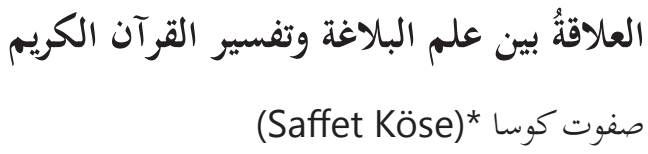

سُليمان حُسَين العميرات (Suliman Husain Alomirat)*

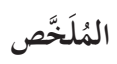

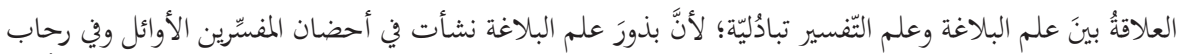

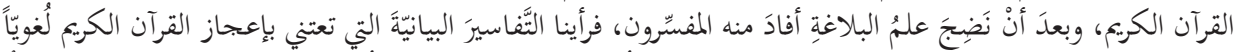

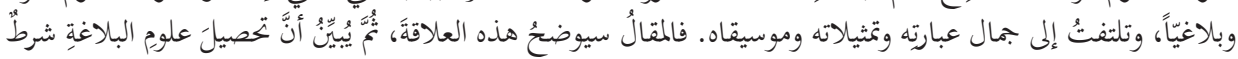

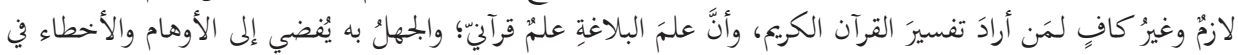

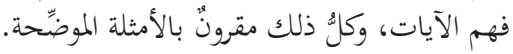

$$
\text { الكلمات المفتاحية: البلاغة، التّفسير، القرآن. }
$$

$$
\text { * * أ.د. ، عميد كليّة العلوم الإسلاميّة ، جامعة إزمير كاتب شبلي ، تركيا }
$$

Prof. Dr., İzmir Kâtip Çelebi Üniversitesi İslâmi İlimler Fakültesi, İzmir/Türkiye, saffet.kose@ikc. edu.tr

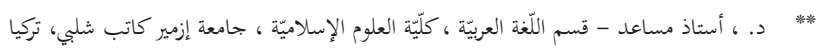

Yrd. Doç. Dr., İzmir Kâtip Çelebi Üniversitesi İslâmi İlimler Fakültesi Arap Dili ve Belagâtı Bölümü, İzmir/Türkiye 


\title{
Belağat İlmi İle Kuran Tefsiri Arasındaki ìlişki
}

\section{$\ddot{\mathbf{O z}}$}

Belağat ilmiyle Kuran tefsiri arasında karşılıklı bir ilişki vardır. Çünkü belağat ilminin asılları, ilk müfessirlerin ellerinde ve Kur'an-1 Kerim'e bağlı olarak ortaya çıktı. Belağat ilminin temelleri sağlamlaştıktan sonra ise müfessirler bu ilimden istifade ettiler. Böylece lüğat ve belağat cihetinden Kur'an'1n mucize oluşuyla ilgilenen ve Kuran'ın ibarelerinin, örneklerinin ve musikisinin güzelliğine yönelen beyani tefsirler görmekteyiz. Bu makale iki ilim arasındaki söz konusu ilişkiyi açıklayacak. Daha sonra da belağat ilminin tahsil edilmesinin çok gerekli bir şart olduğunu, ancak Kur'an-1 Kerim'i tefsir etmek isteyenler için yeterli olmadığını ve belağat ilminin Kur'anî bir ilim olduğunu, bu ilmi bilmemenin, ayetlerin manalarını anlamada hataya düşmeye sebep olduğunu açıklayacak. Bütün bu hususlar makalede açıklayıcı örneklerle birlikte sunulmuştur.

Anahtar Kelimeler: Belağat, Tefsir, Kur'an.

\section{The Relation Between Rhetoric Science and Interpration of Quran}

\begin{abstract}
The relationship with the Balaghat (Rhetoric) Science and Qur'an Tafsir are to help each other. Because the originals of Balaghat Science appeared on lap of the first commentators (mufassir) and in the field of al-Qur'an al-Karim. After the consolidation of basis of Balaghat Science commentators have benefited from this science. So, we see statement commentaries (Bayânî Tafsirs) dealing with the miracle of the Qur'an from aspect of the vocabulary and eloquence, and towards the beauty of expression of Qur'an, its examples and its music. This article will explain the relationship between these two science. Then it will also announce that a necessary condition for the learning of Balaghat (Rhetoric) Science, but for those who want to interpretation of the Quran is not enough, however, the Balaghat science is a Qur'anic science. Otherwise, not to know this science, to understand the meaning of the verses causes the mistake. The article brought to explanatory examples about these.
\end{abstract}

Keywords: Balaghat, Tafsir, Qur'an. 


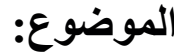

\section{أوَّلاً: أثر المفسرّين في الأَّرس البلاغيّ:}

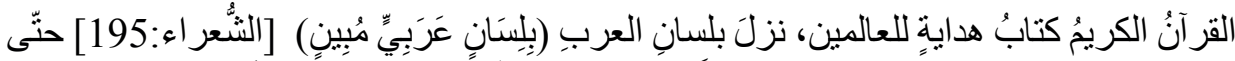

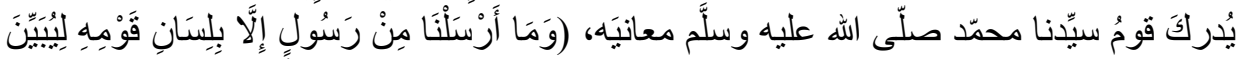

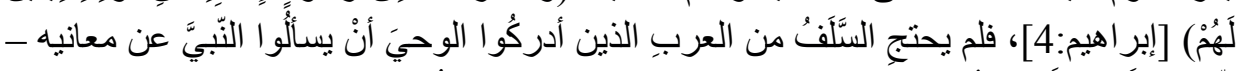

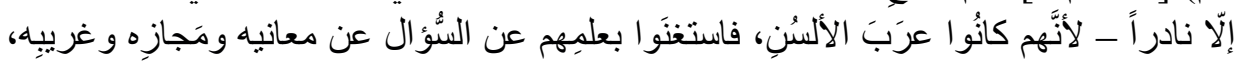

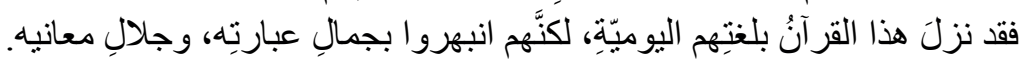

أمّا في العصرِ العبّاسيّ - وبعد اتَّساع رُقعةِة الدَّولة، ودخول الأعاجم في الإسلام، وكثرةِ اللَّحْنِ

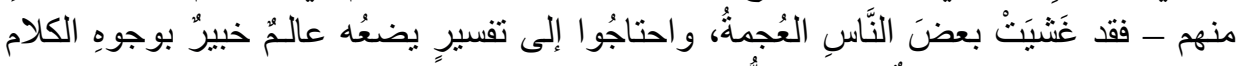

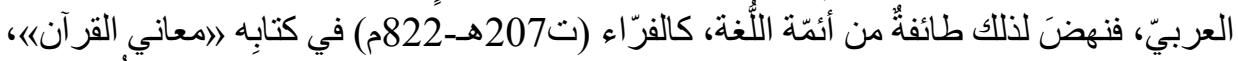

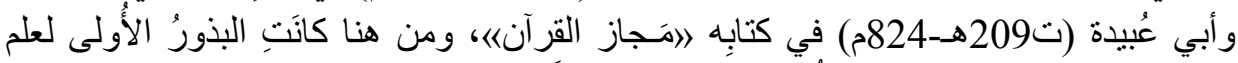

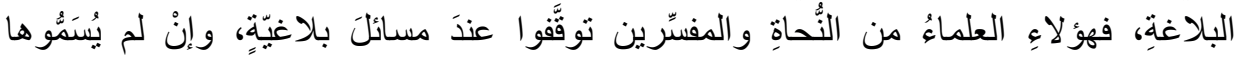
بالمصطلحاتِ التي اتَقق عليها البلاغيّون لاحقاً.

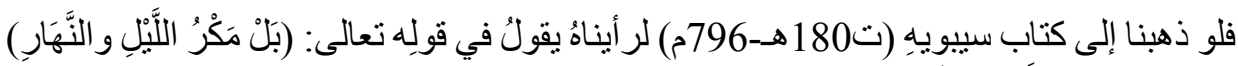

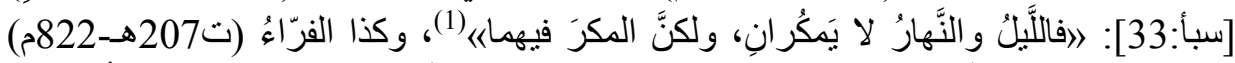

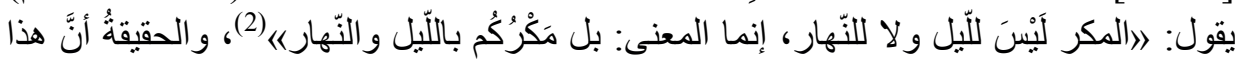

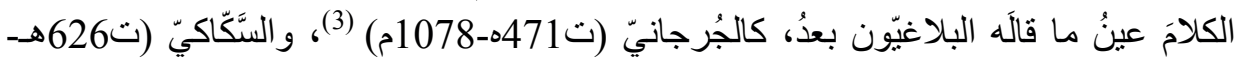
1229م) (4)، و إنْ أسَّوه (المجازَ العقليّ).

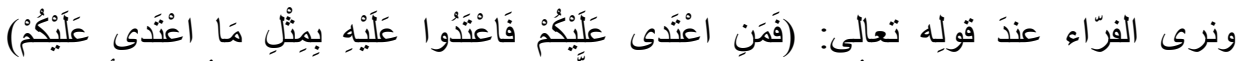

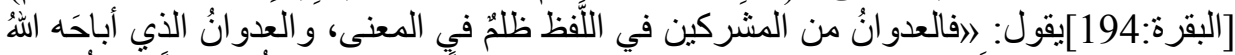

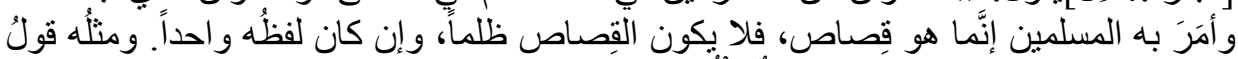

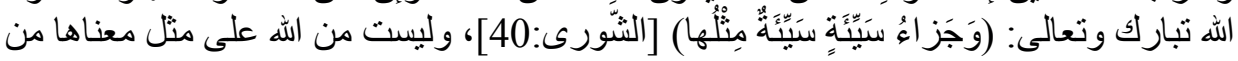

انظر: الكتاب، سييويه (ت180هـ-796م)، تحقيق: عبد السَّلام هارون، مكتبة الخانجي، القاهرة، ط3،

176/1. 1988

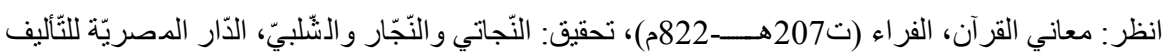

$$
\text { و التّرجمة - مصر ، ط1. 363/2. }
$$

انظر : أسر ار البلاغة، الجرجانيّ (ت 471هـ-1078م)، تحقيق: محمود شاكر، مطبعة المدنيّ بالقاهرة، دار

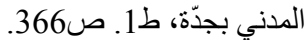

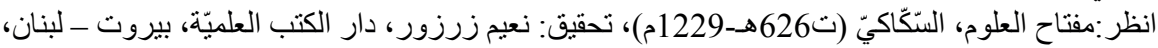




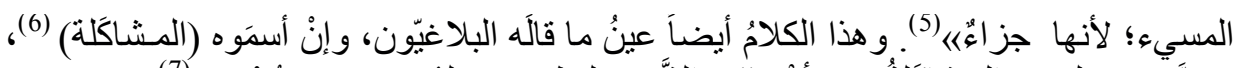

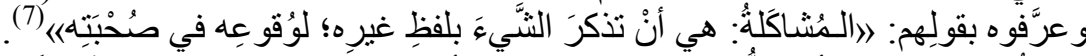

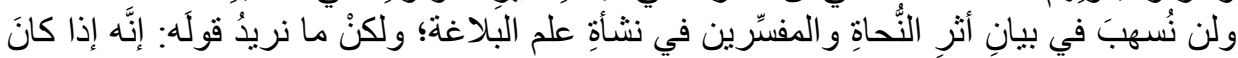

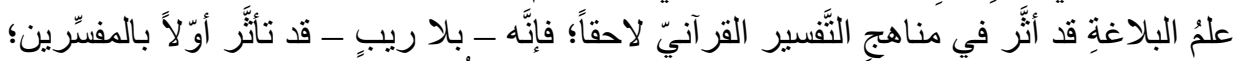

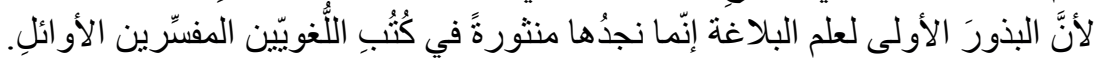

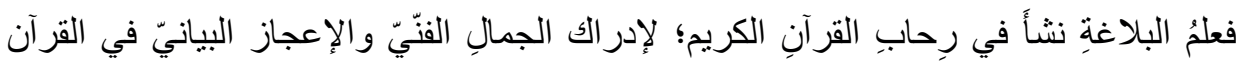

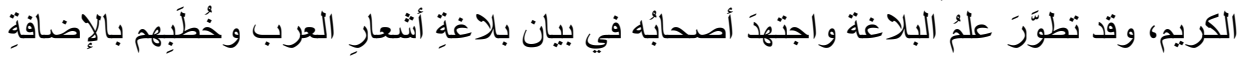

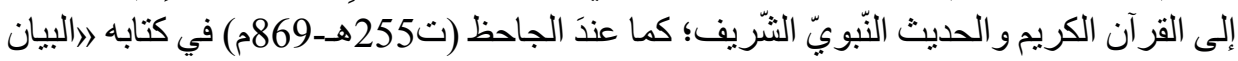

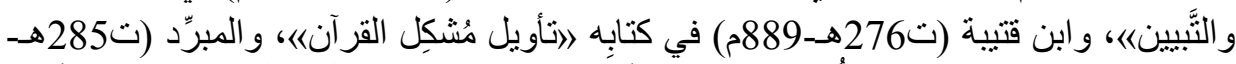

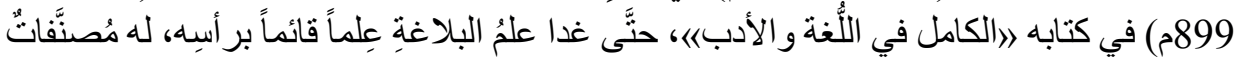
تُعنى به؛ منل: كتاب 》البديع)《، لابن المعتزّ (ت

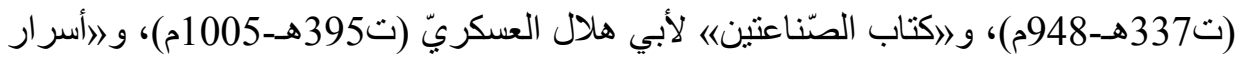

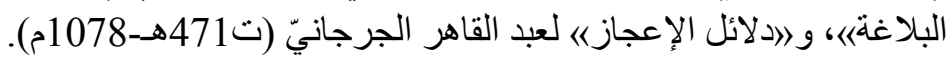

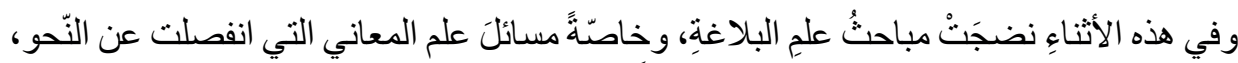

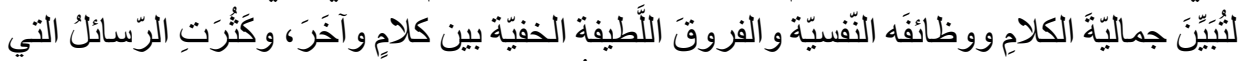

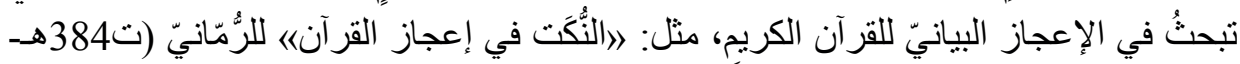

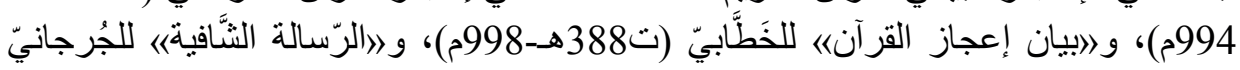

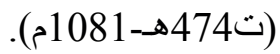

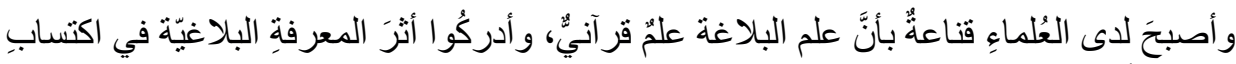

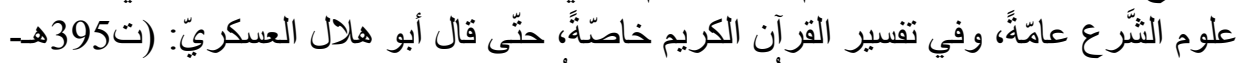

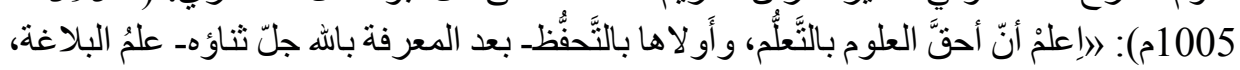

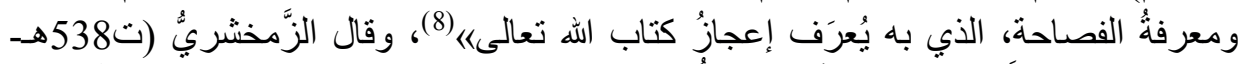

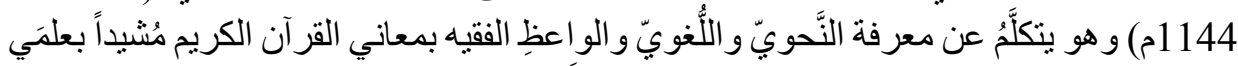

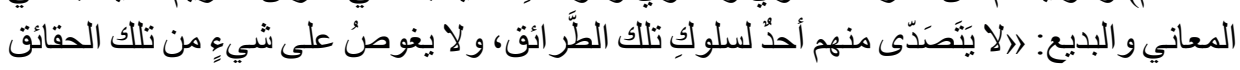

انظر : معاني القرآن للفرّاء 117/1.

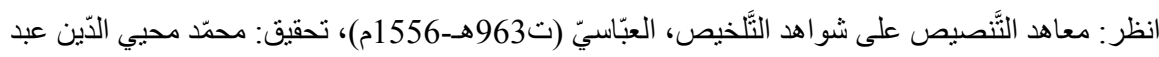

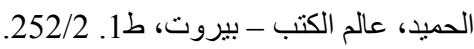

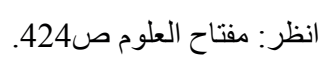

انظر : كتاب الصّناعتين، أبو هلال العسكريّ (ت395هــ-1005م)، تحقيق: عليّ محمّد البجاويّ ومحمّد أبو 


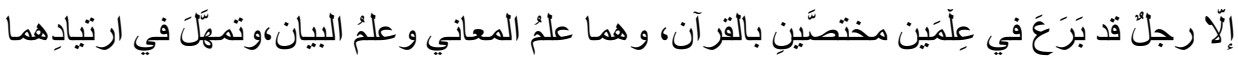

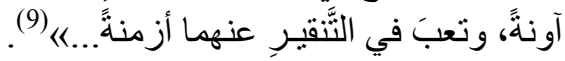

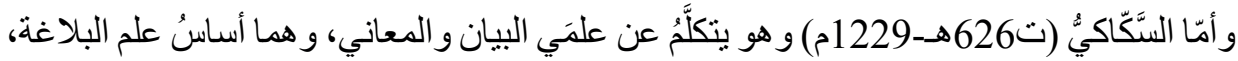

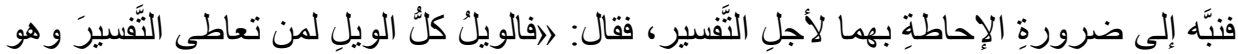
فيهما راجلُه (10).

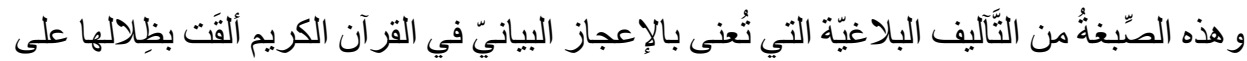

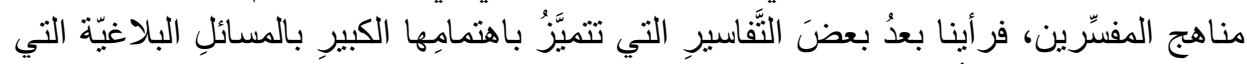

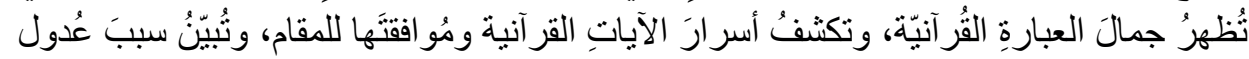

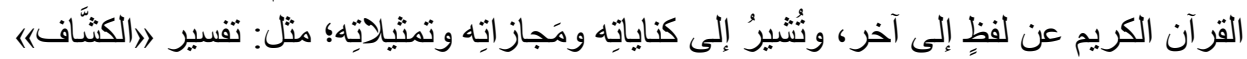

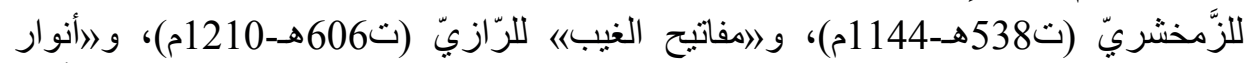

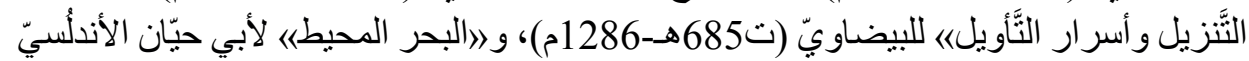

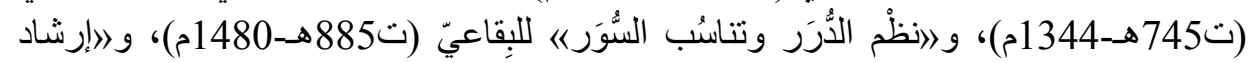

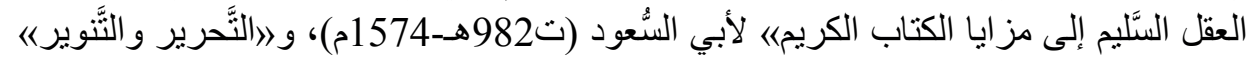

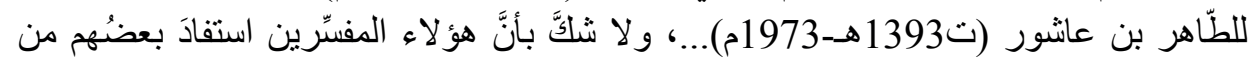

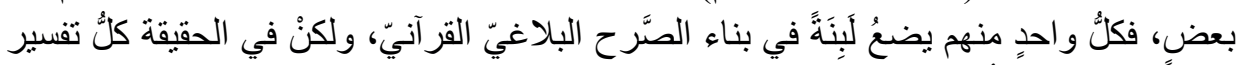

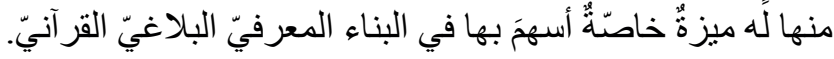

\section{ثانياً: أثرُ المعرفة البلاغيّة في تفسير القرآن الكريم.}

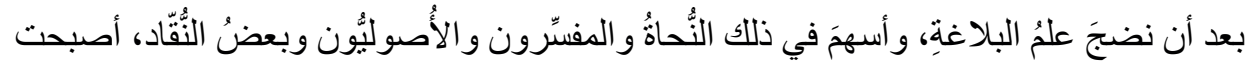

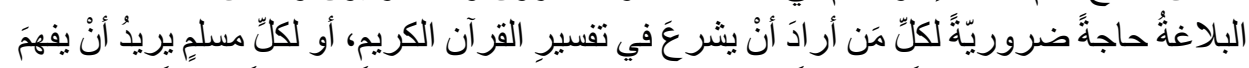

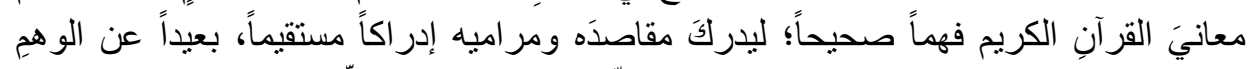

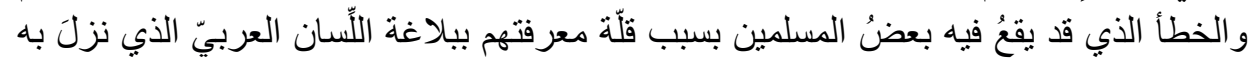

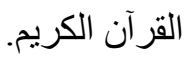

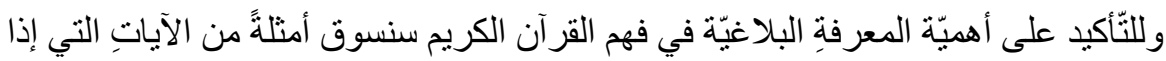

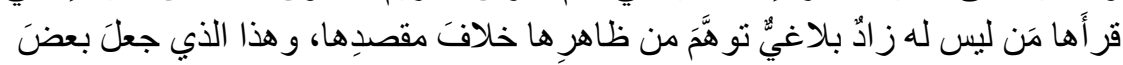

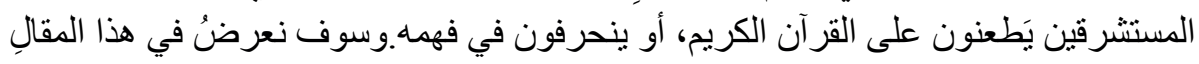




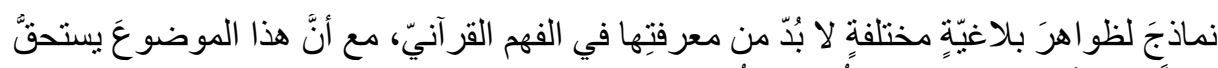

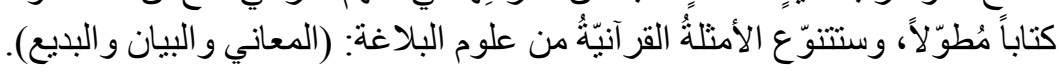

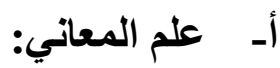

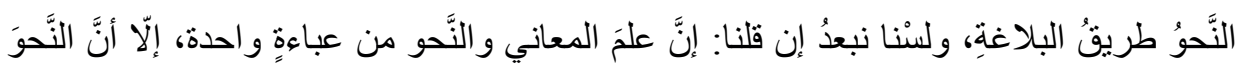

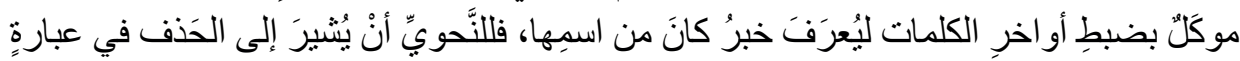

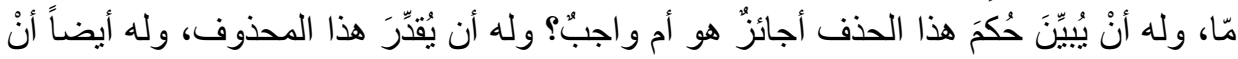

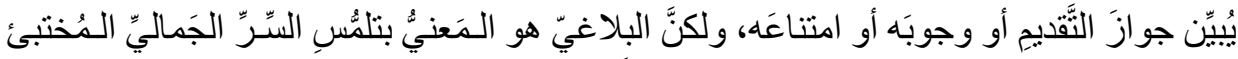

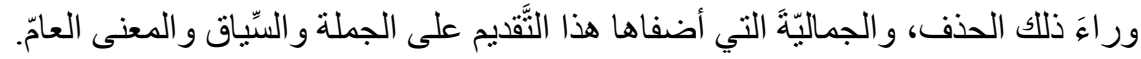

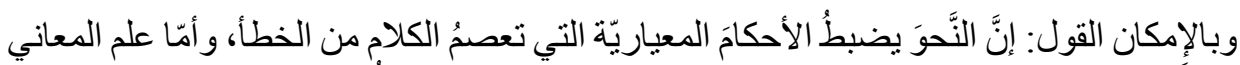

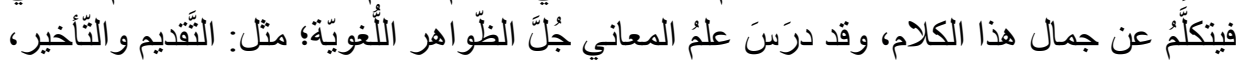

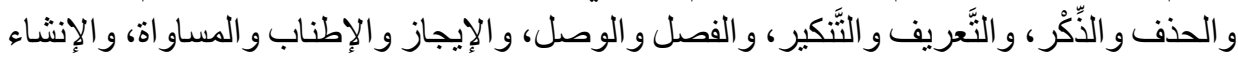

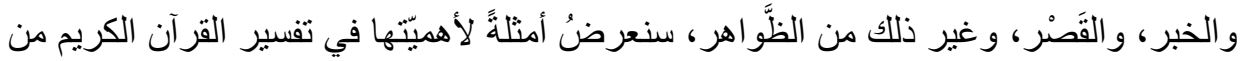
خلال ظواهر : (الحذف، القََم، عود الضّمير ).

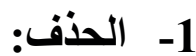

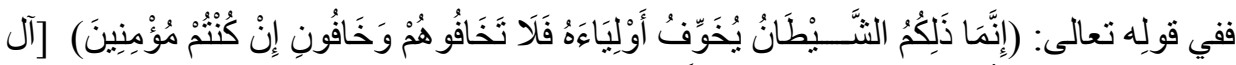

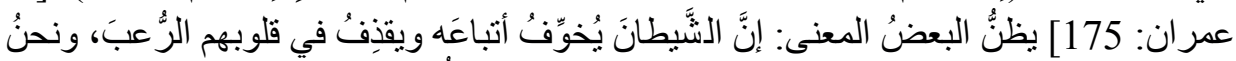

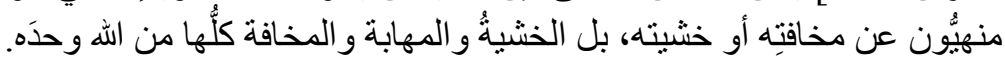

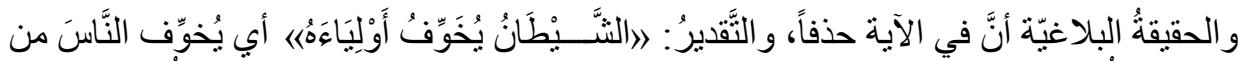

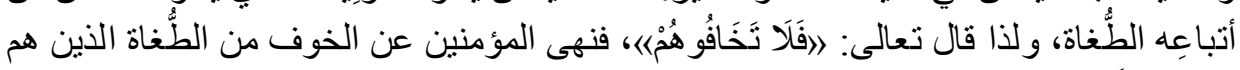
أولياءُ الثنَّيطان.

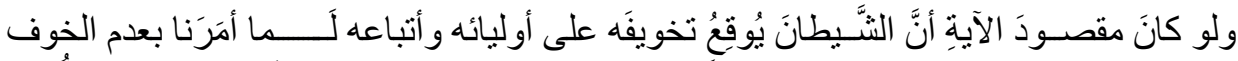

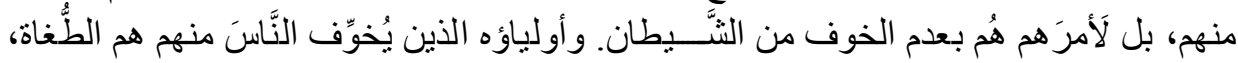

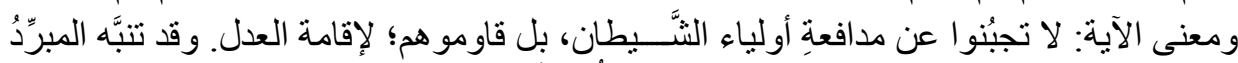

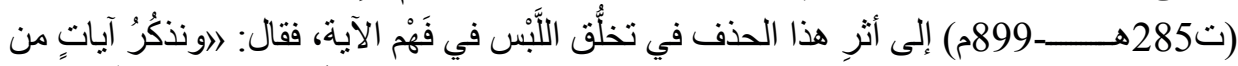

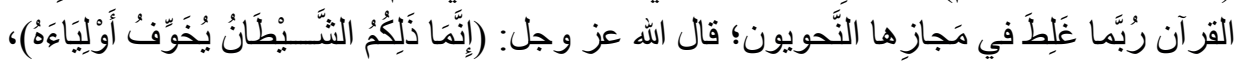




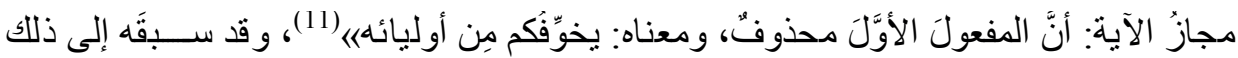

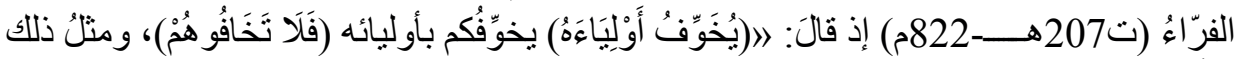

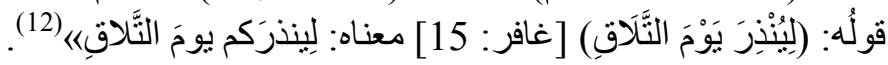

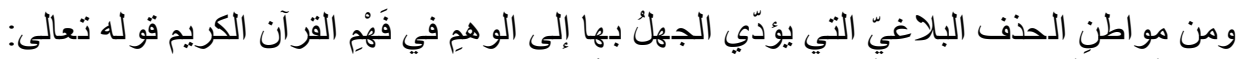

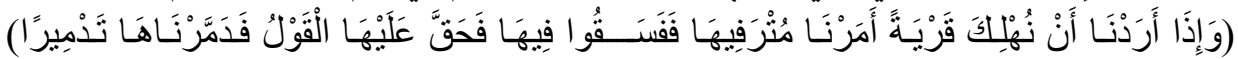

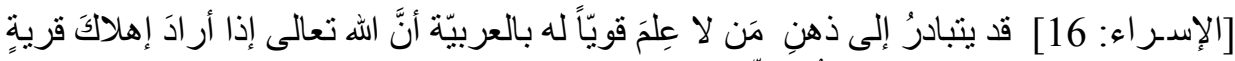

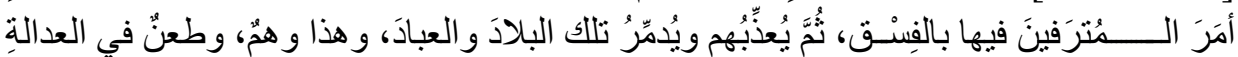

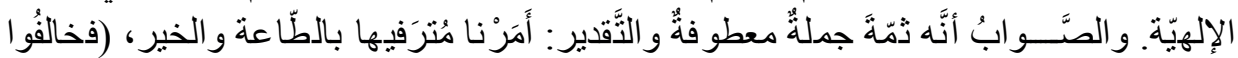

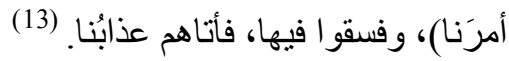

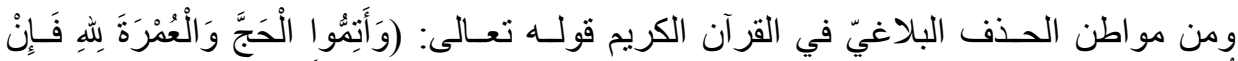

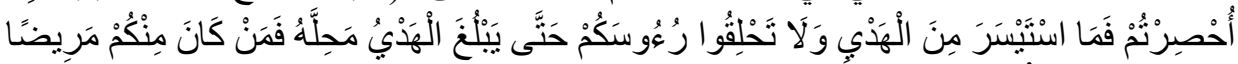

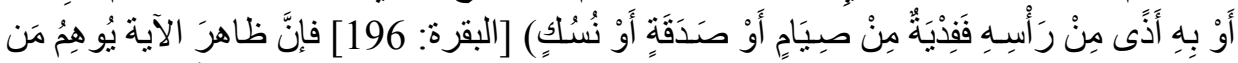

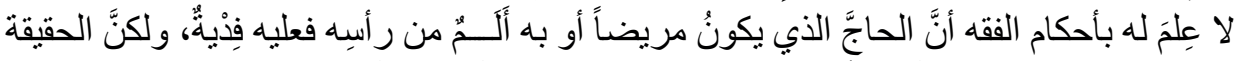

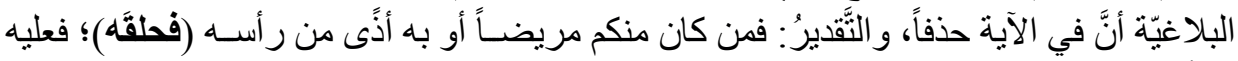

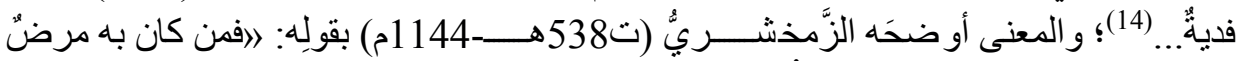

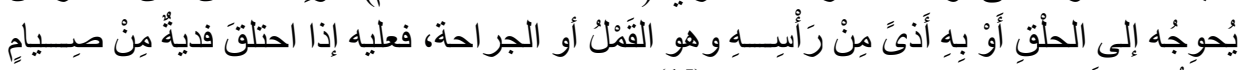

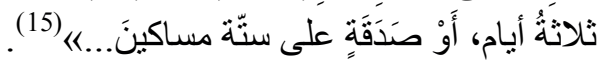

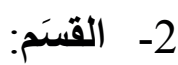

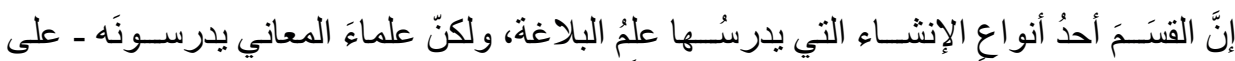

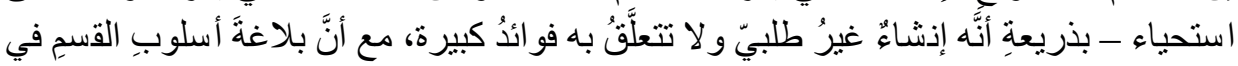

انظر: الكامل، للمبرِّد (ت285ه-8998)، تحقيق د. محمّد أحمد الدّالي، مؤسّسة الرّسالة، ط5، 2008م.

انظر : معاني القرآن للفرَّاء 248/1.

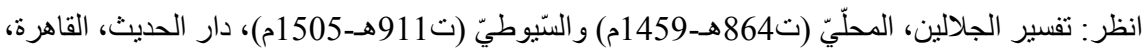
ط.168.

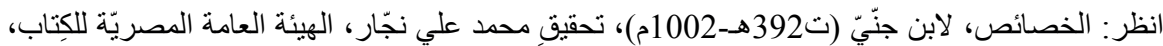

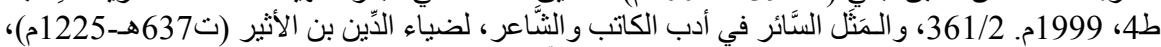

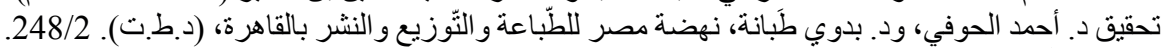




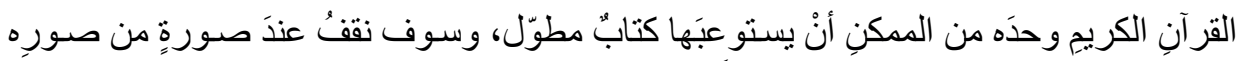

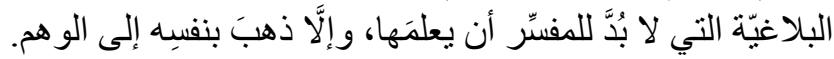

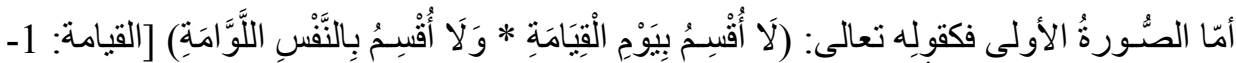

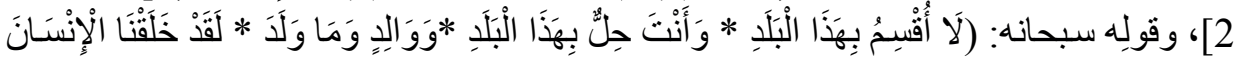

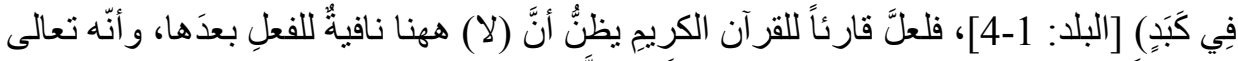

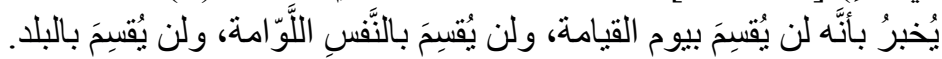

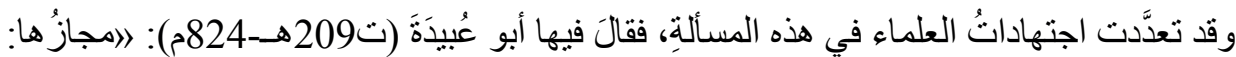

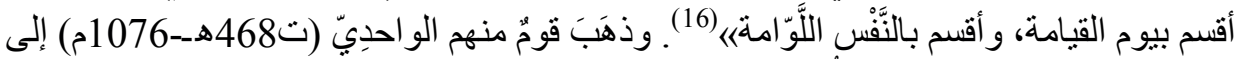

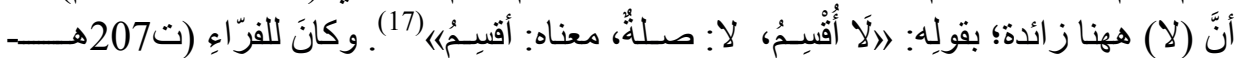

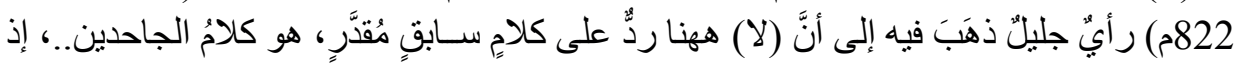

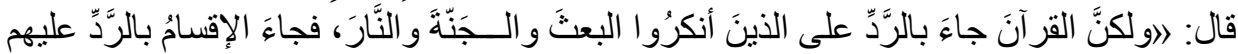

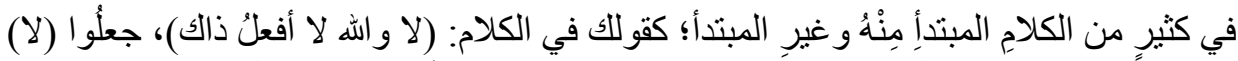

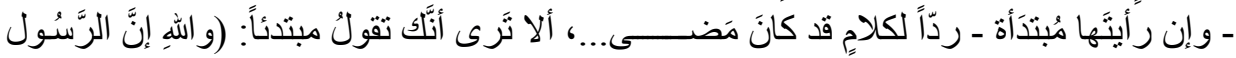

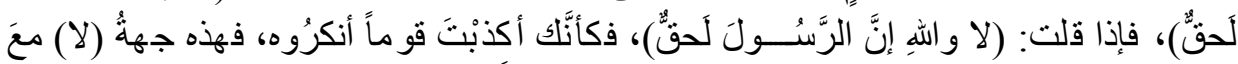

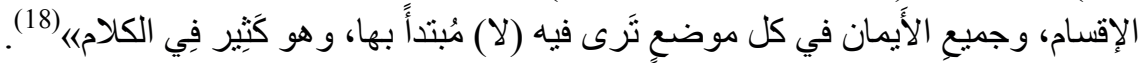

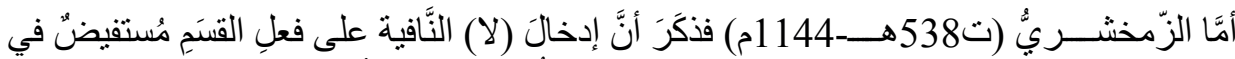

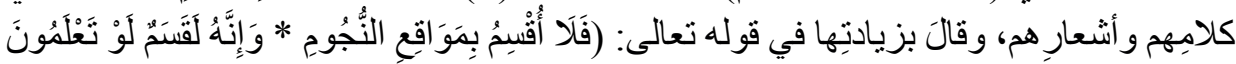

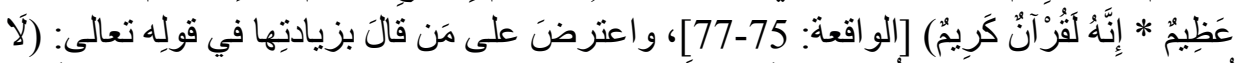

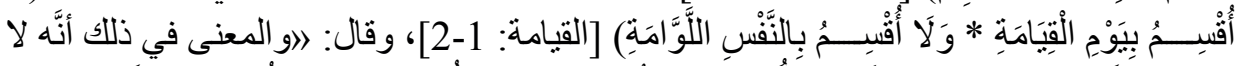

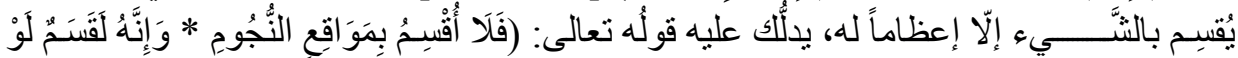

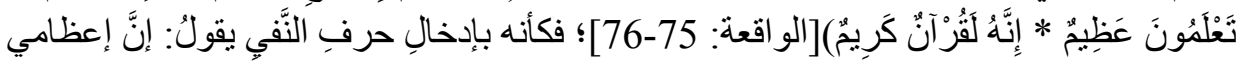

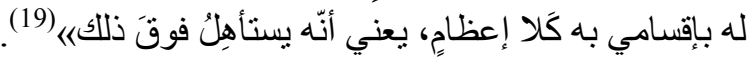

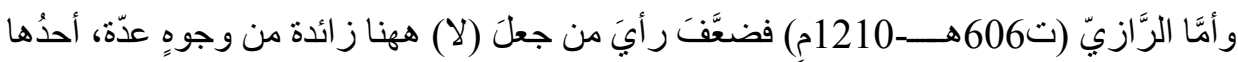

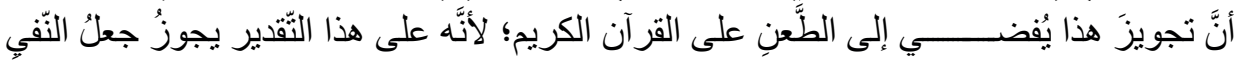

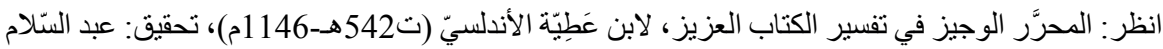

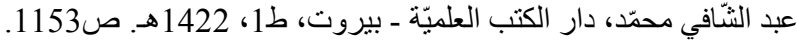

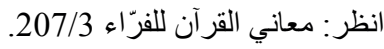




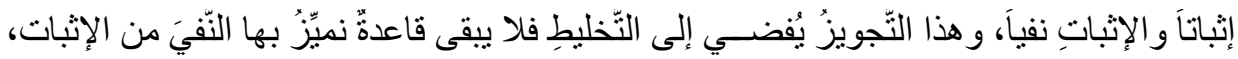

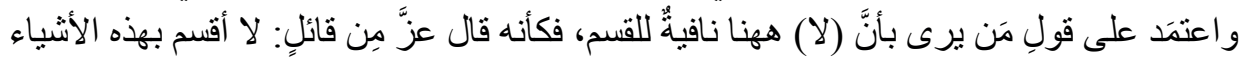

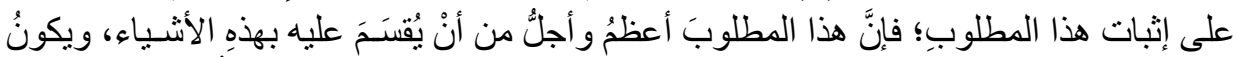

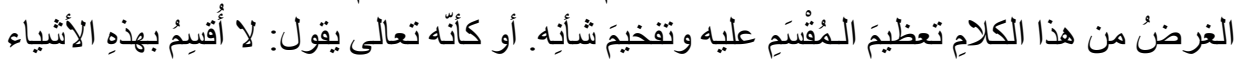

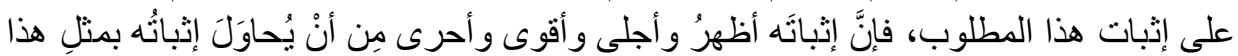
القسم (20)

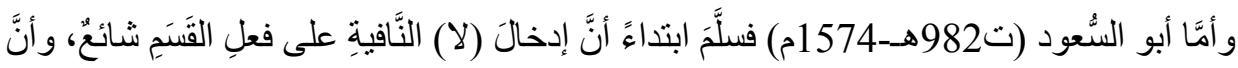

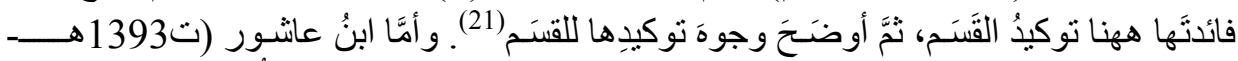

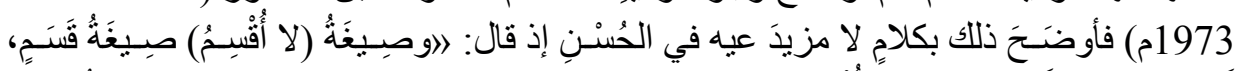

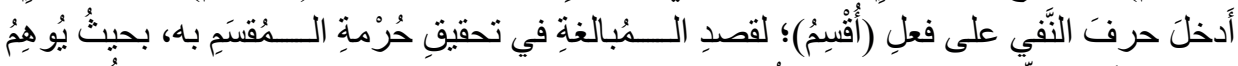

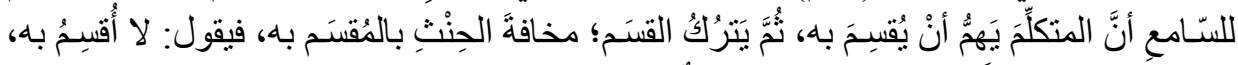

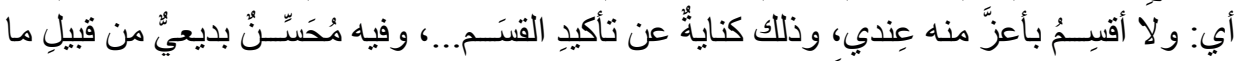

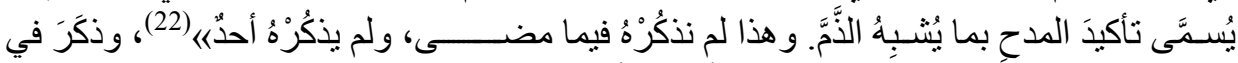

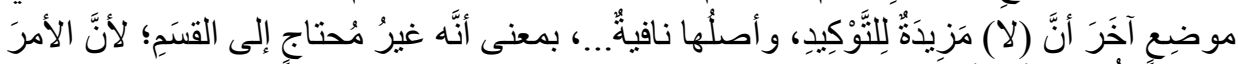

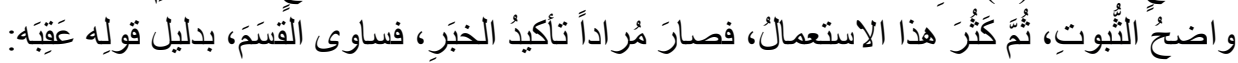

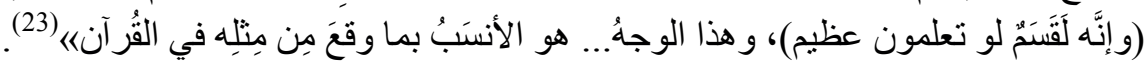

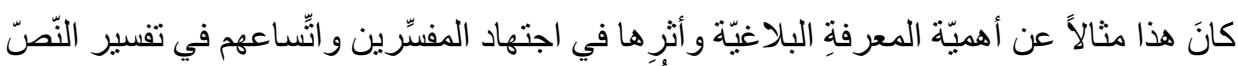

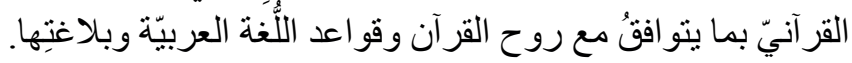

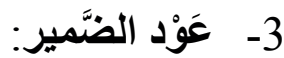

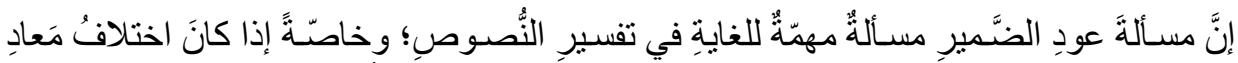

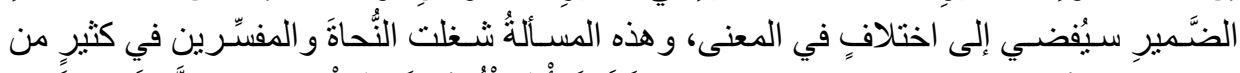

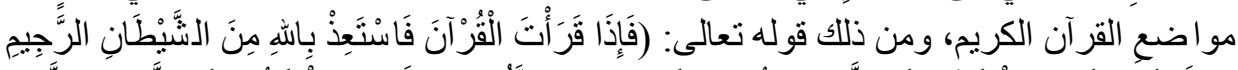

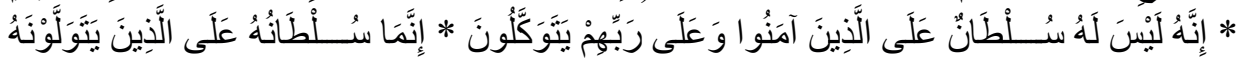

انظر: مفاتيح الغيب، لفخر الدّين الرّازيّ (ت606هـ-1210م)، دار إحياء التّراث العربيّ، بيروث، ط3، 1420هـ.

.720/30

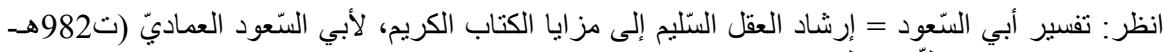

1574م)، دار إحياء التّراث العربيّ - بيروت. 64/9.

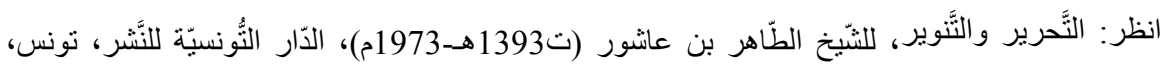

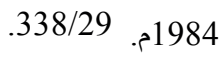

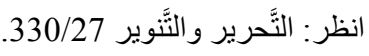




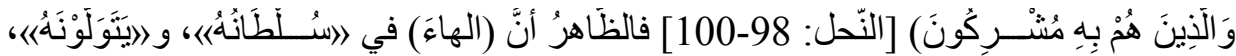

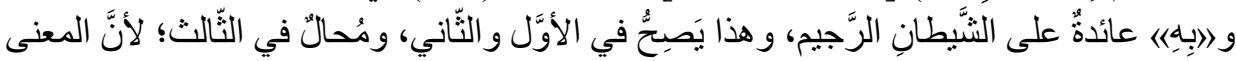

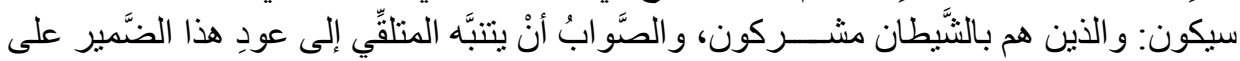

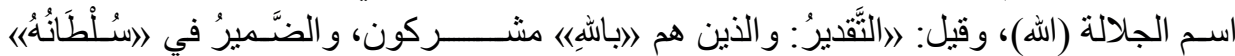

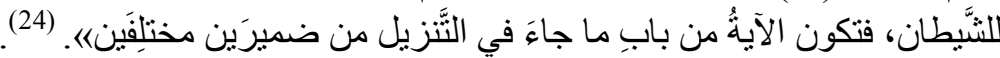

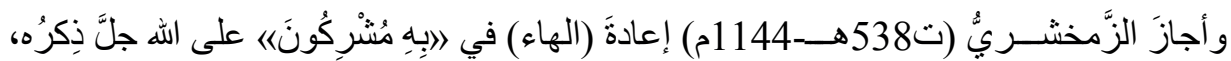

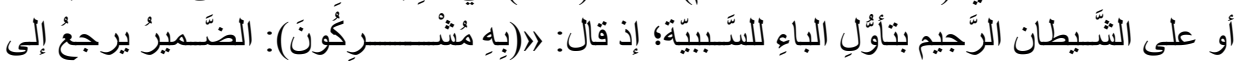

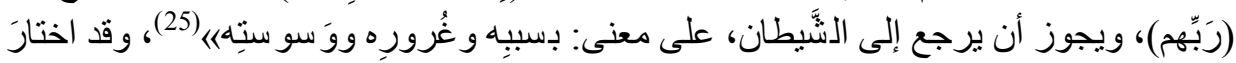

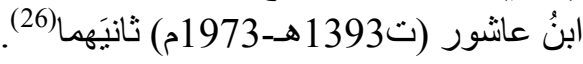

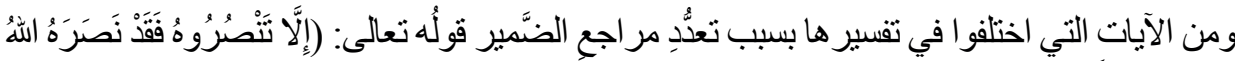

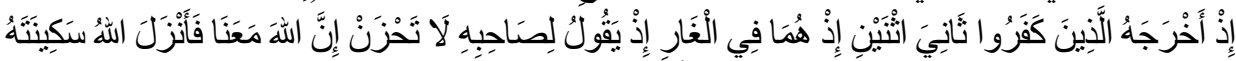

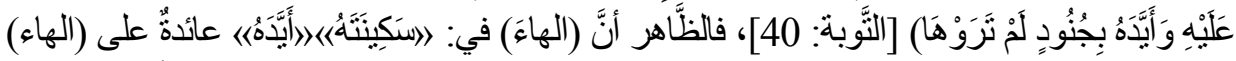

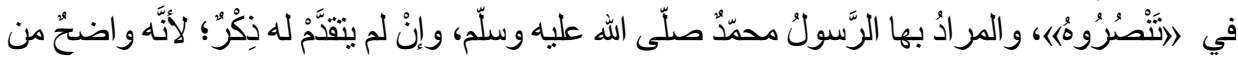

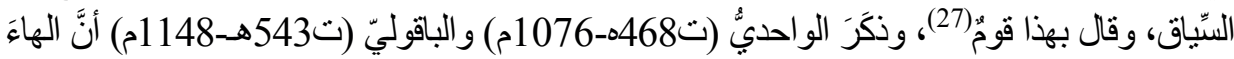

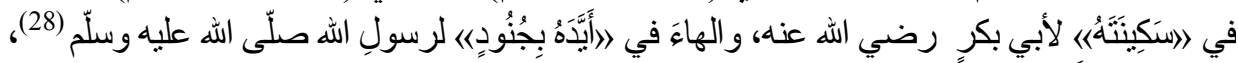

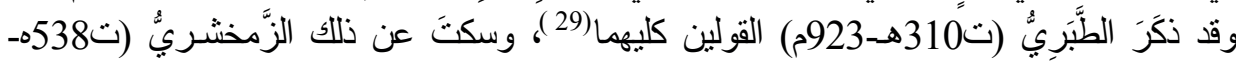

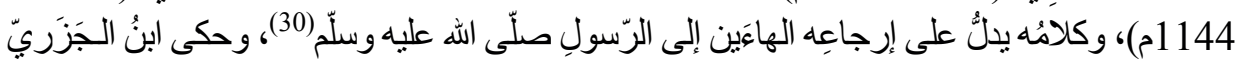

انظر : النَّحريز و النَّتوير 279/14.

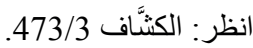

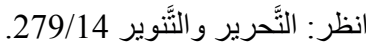

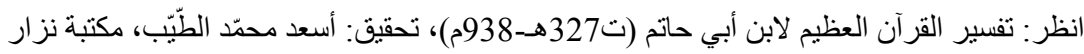

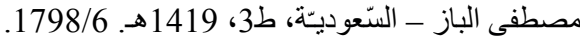

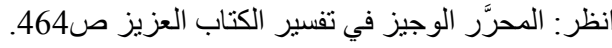

انظر : تفسير الطُّبرَيّ (جامع البيان في تأويل القرآن)، لأبي جعفر الطَّبريّ (ت310 310هـ-923م)، تحقيق: أحمد

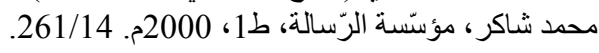




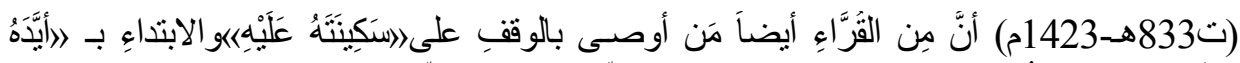

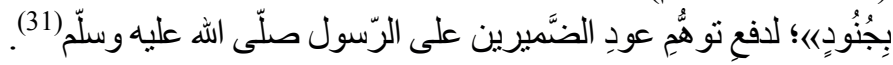

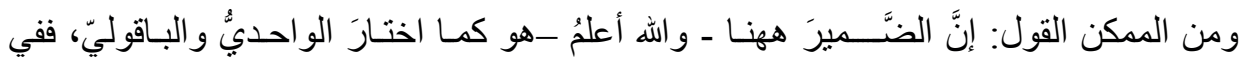

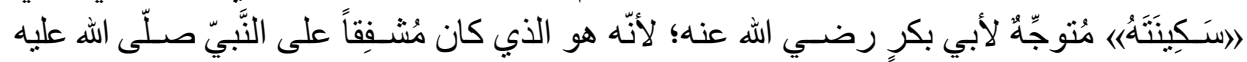

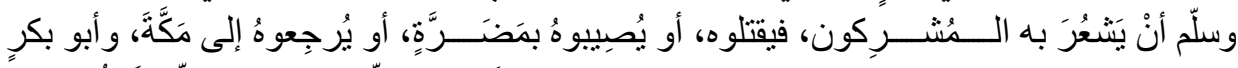

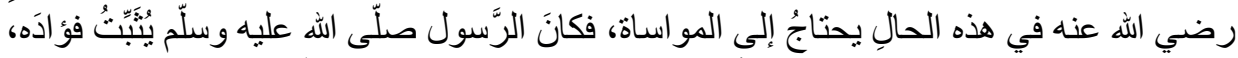

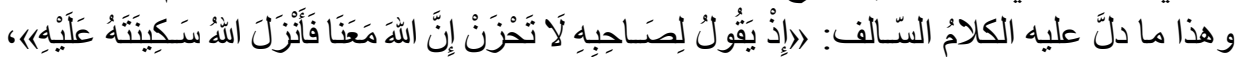

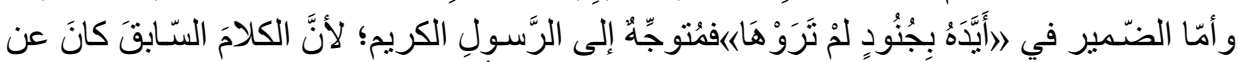

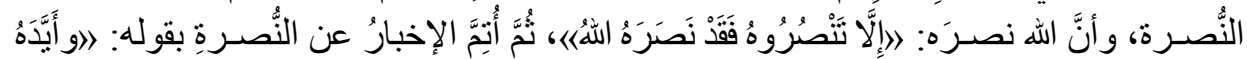

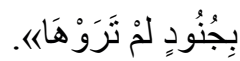

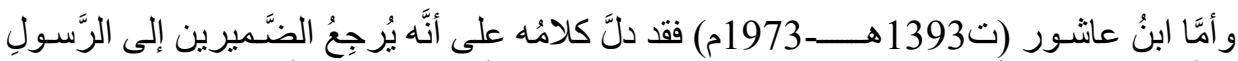

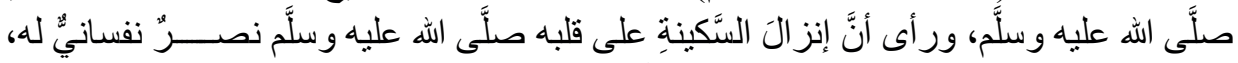

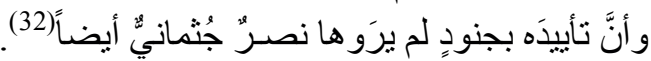

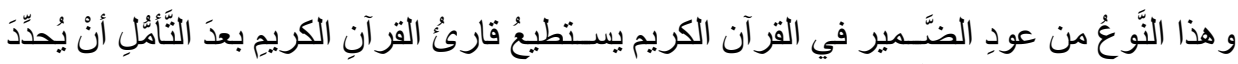

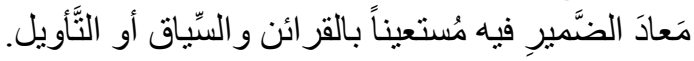

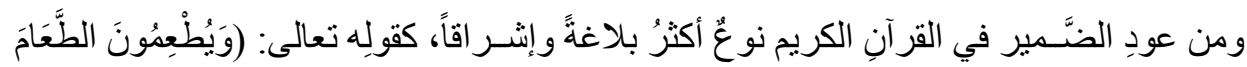

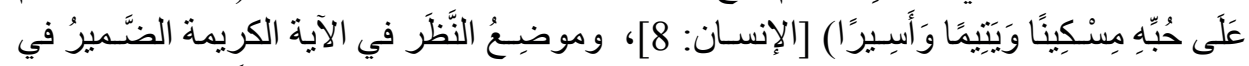

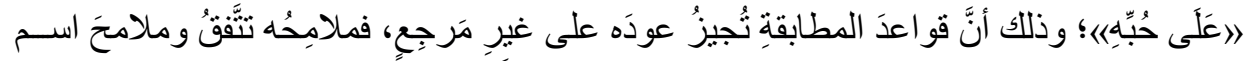

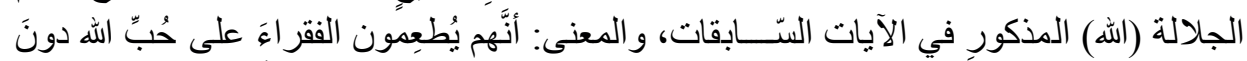

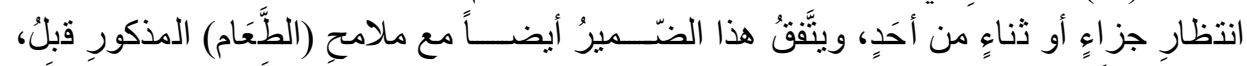

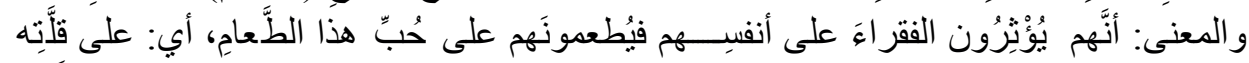

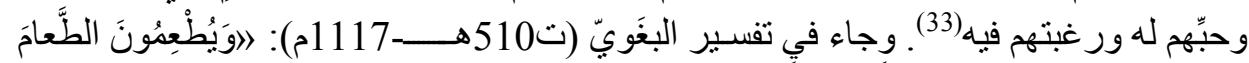

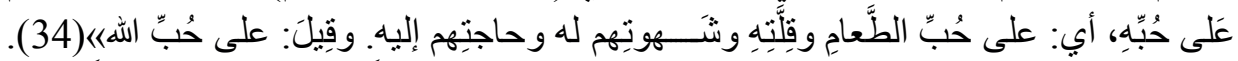

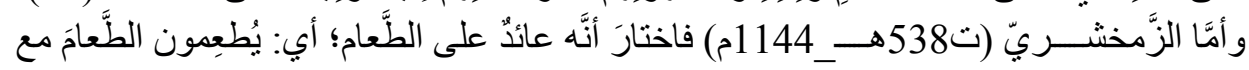

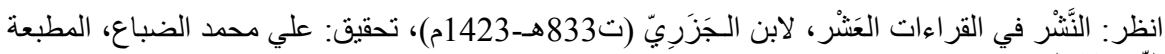

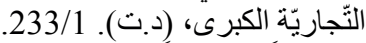

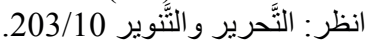
انظر: المحرَّر الوجيز في تفسير الكتاب العزيز صبر ص1158.

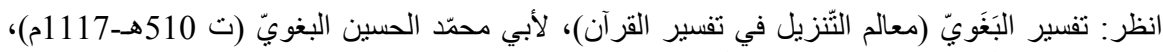

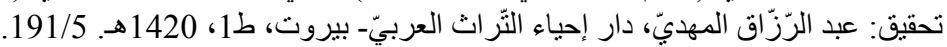




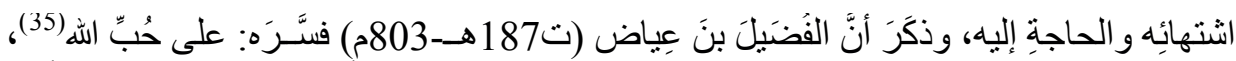

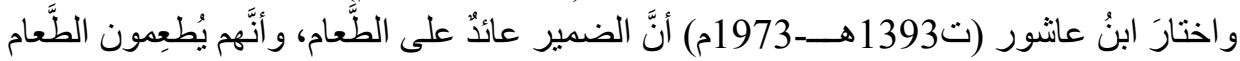
وهم في حاجةٍ إليه وبهم خَصَاصنَة (36).

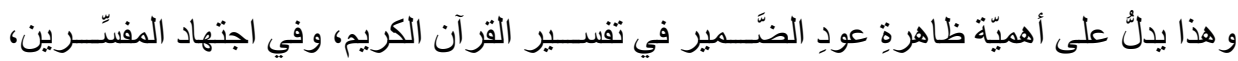

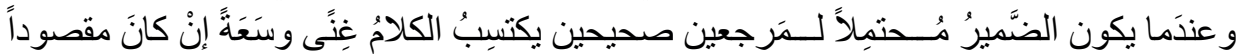

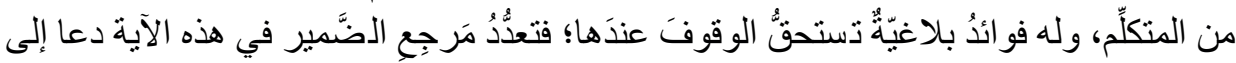

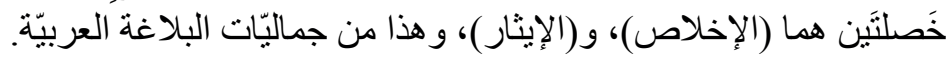

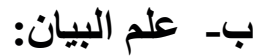

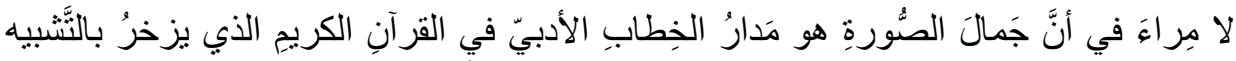

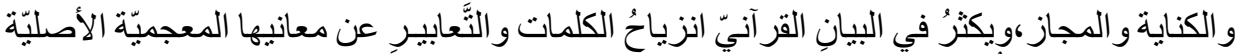

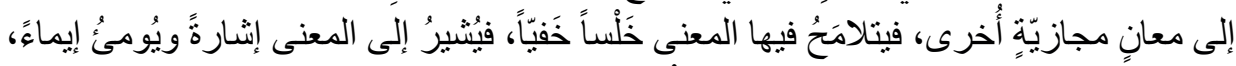

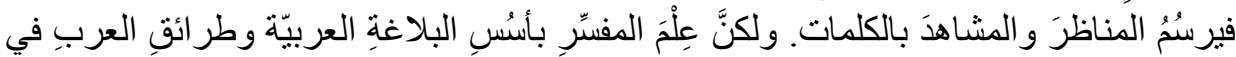

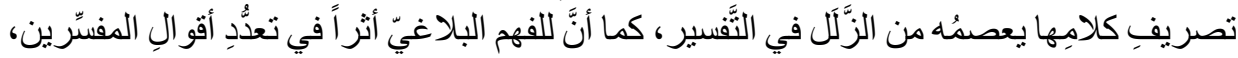

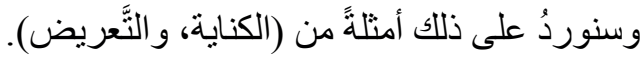

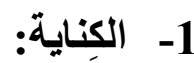

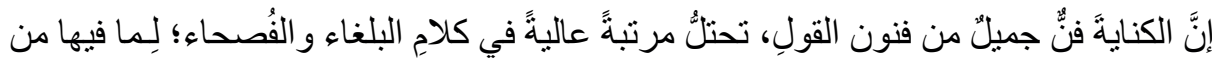

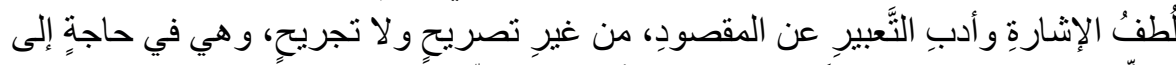

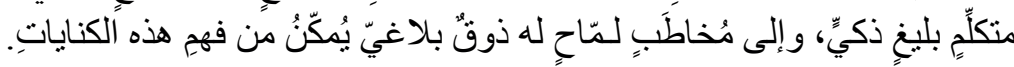

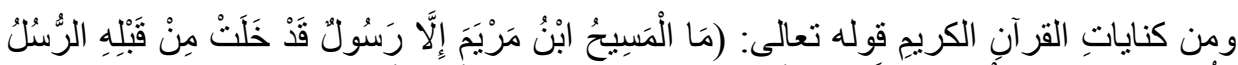

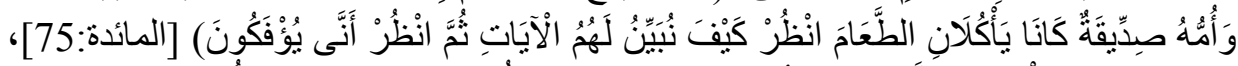

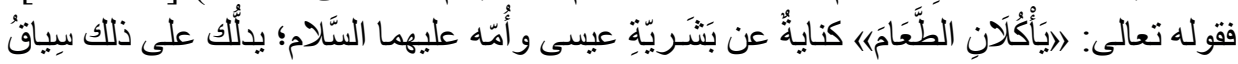

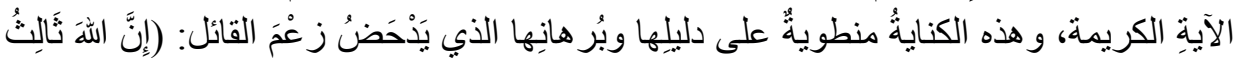

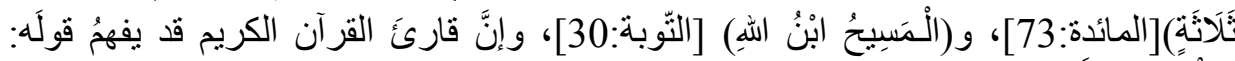

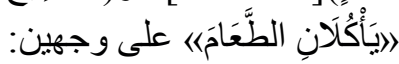
• أوّلهها: تناوُتُ الطَّعام كما يفعلُ النّاسُ جميعاً، و هذا هو المعنى الوضعيّ للتَّعبير. 


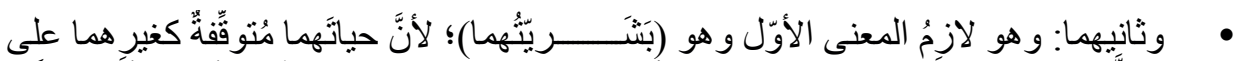

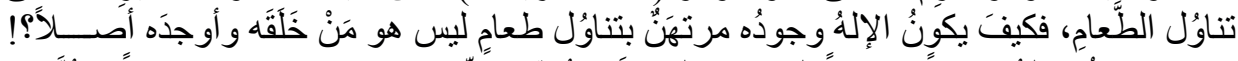

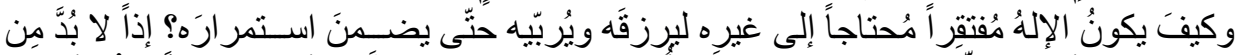

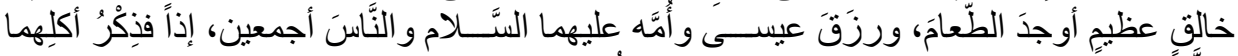

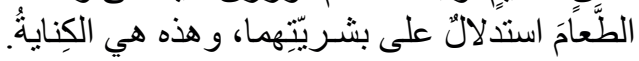

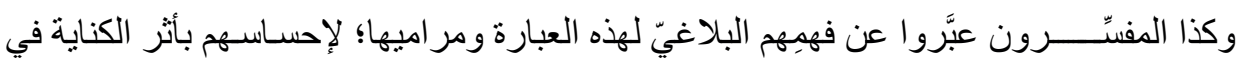
تقويةِ المعنى وتسديده.

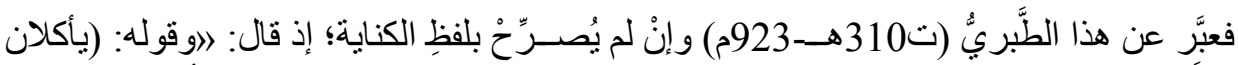

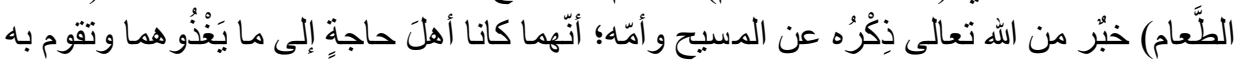

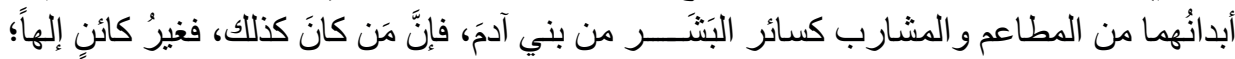

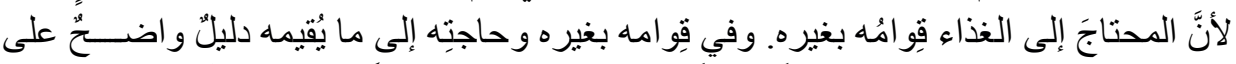

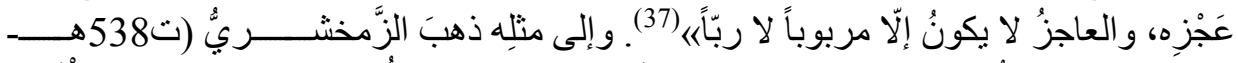

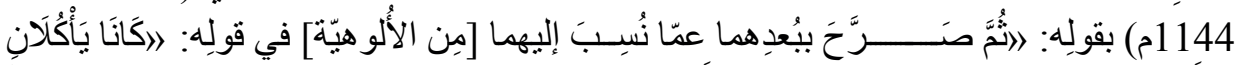

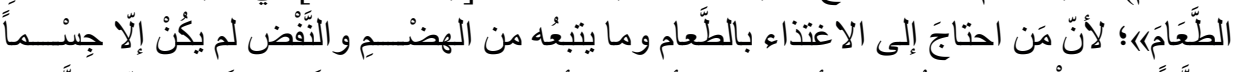

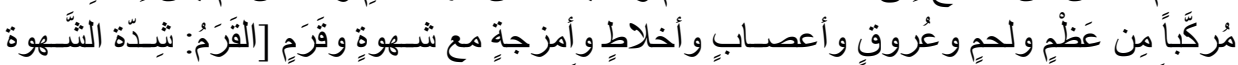

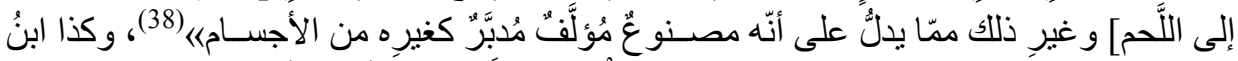

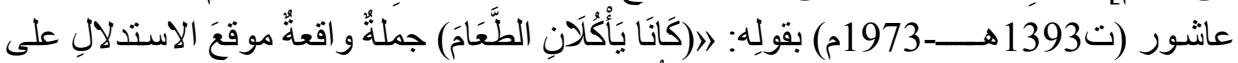

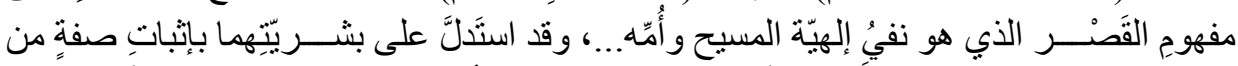

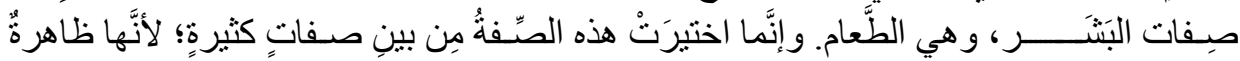

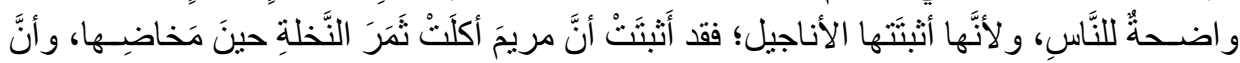

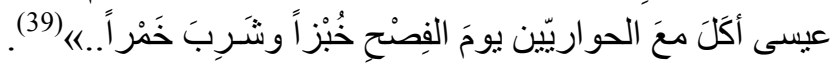

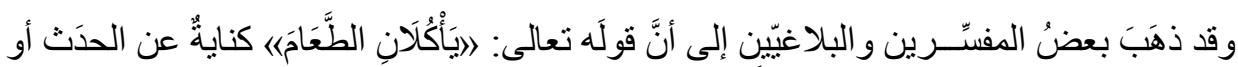

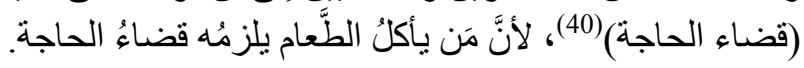

$$
\begin{aligned}
& \text { انظر : تفسير الطَّبريّ 485/10. } \\
& \text { انظر : الكثَّاف 665/1. } \\
& \text { انظر : التَّحرير و النَّوير 286/6. }
\end{aligned}
$$

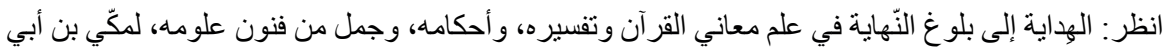

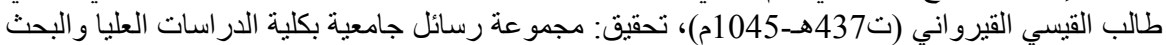

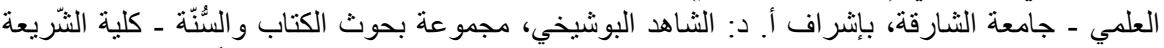

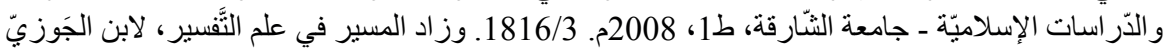




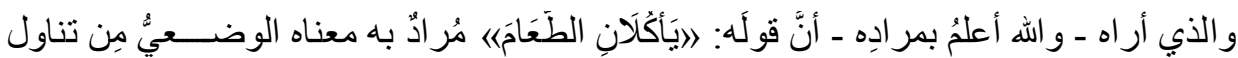

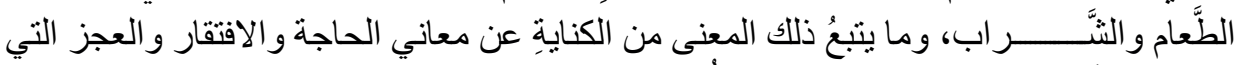

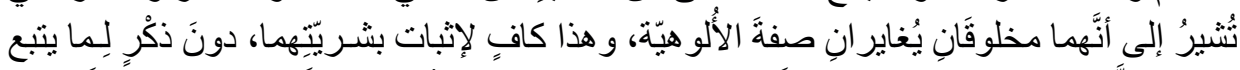

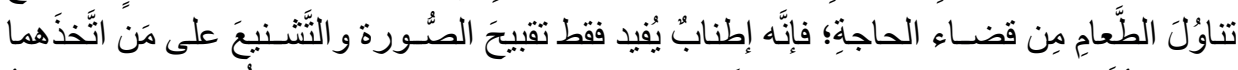

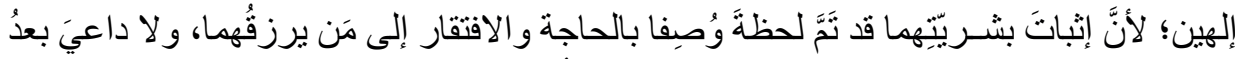

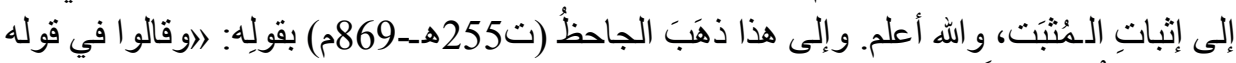

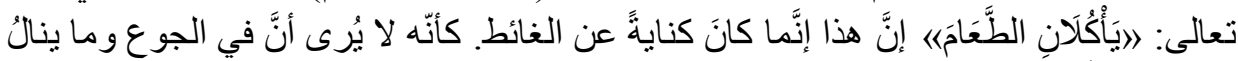

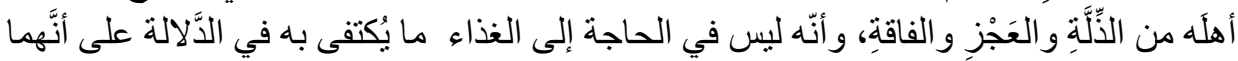

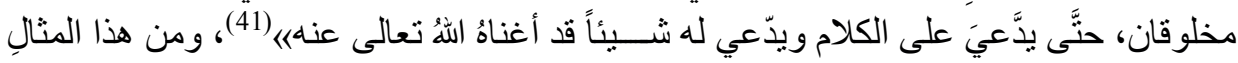

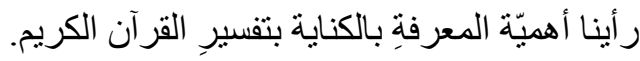

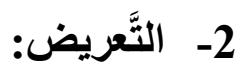

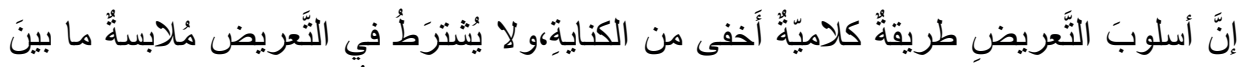

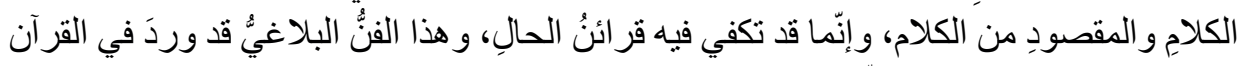

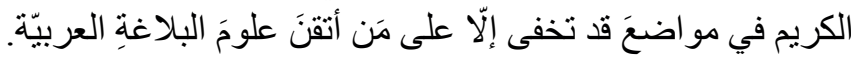

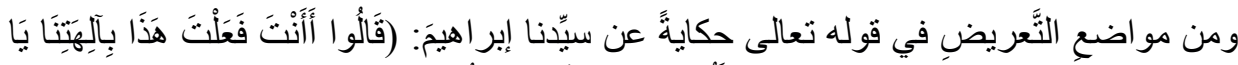

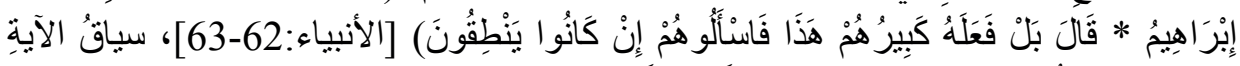

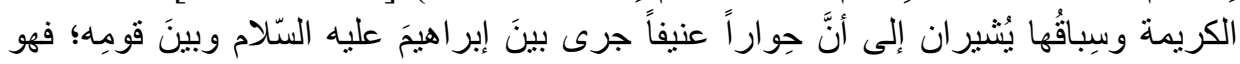

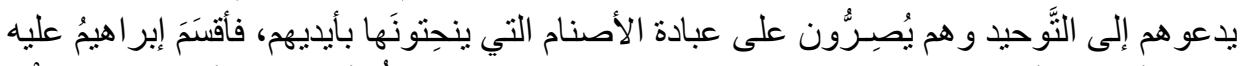

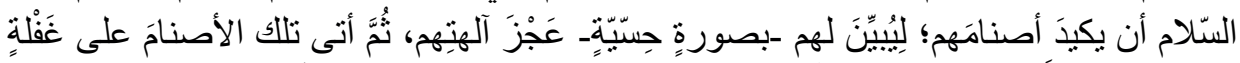

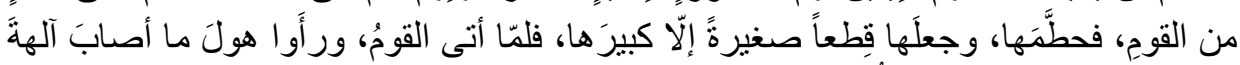

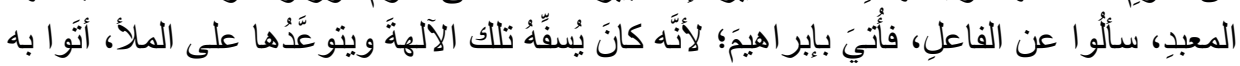

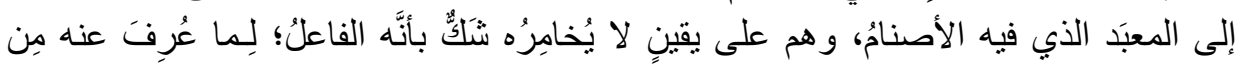

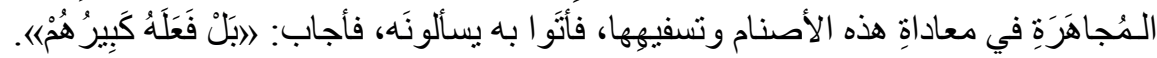

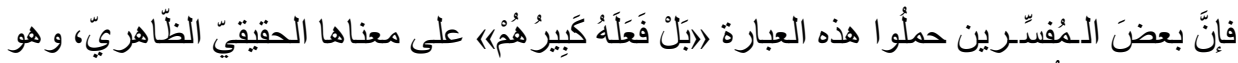

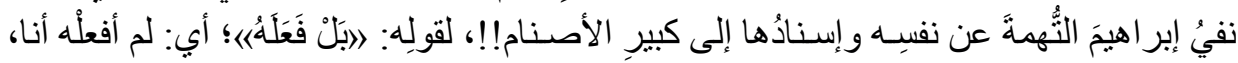

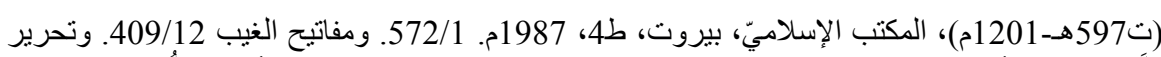

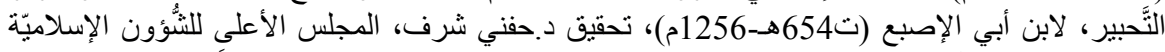

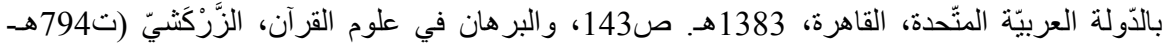

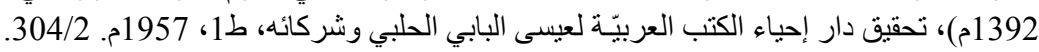




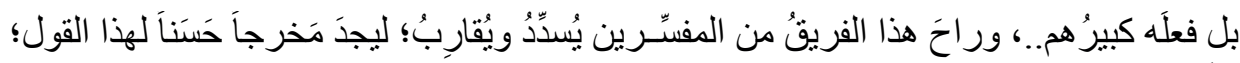

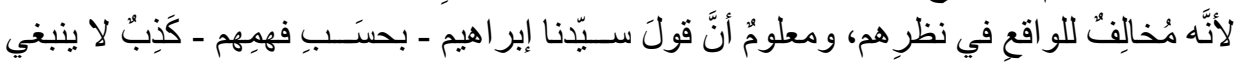

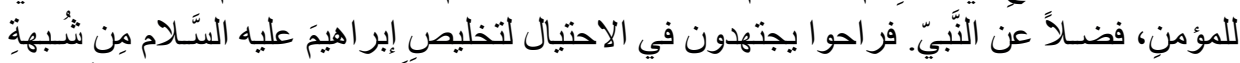

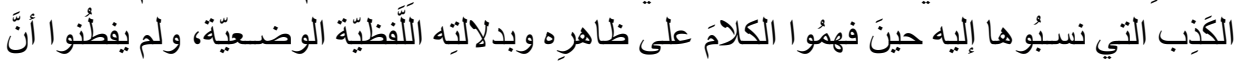

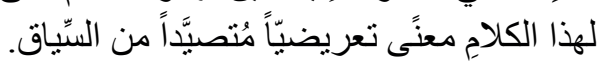

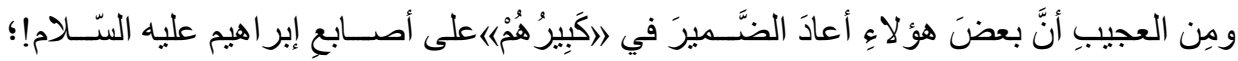

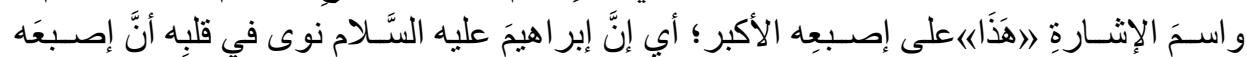

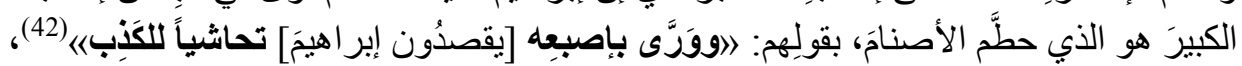

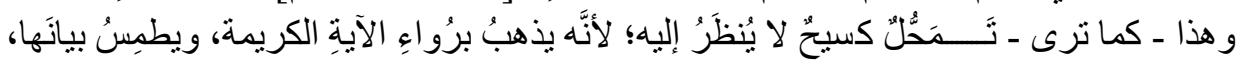

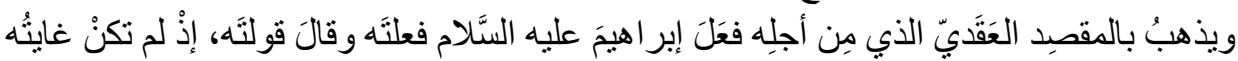

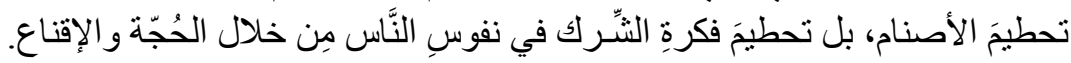

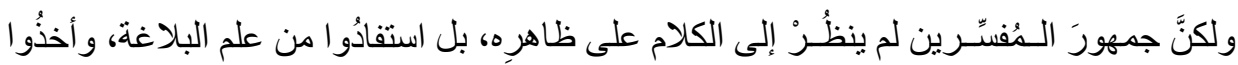

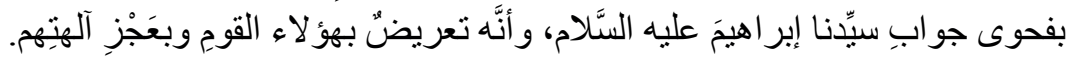

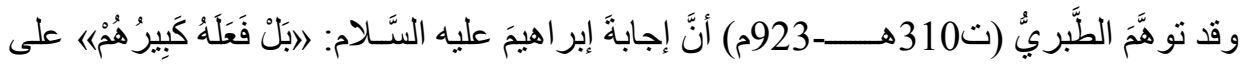

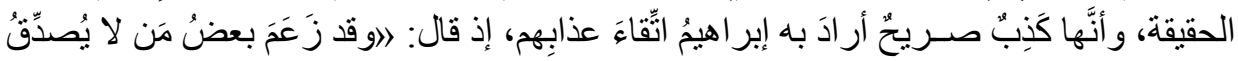

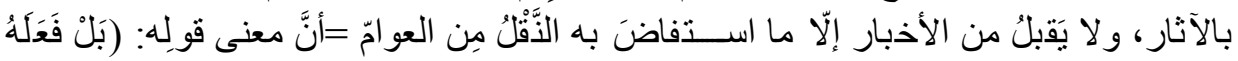

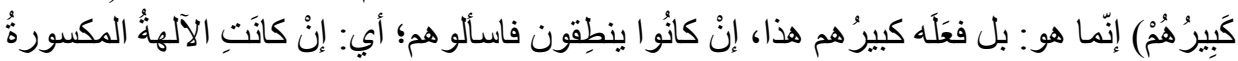

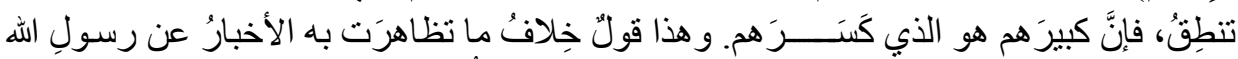

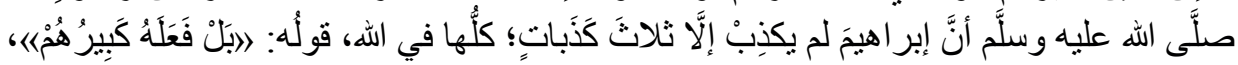

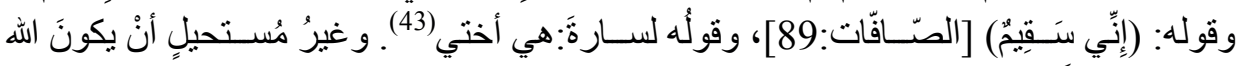

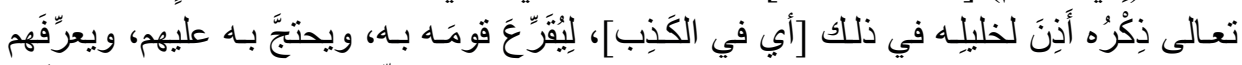

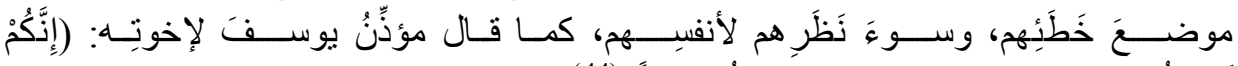

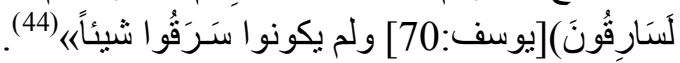

انظر: أيسَرَ التَّاسير لكلام العليّ الكبير، لجابر بن موسى بن عبد القادر بن جابر أبو بكر الجزائريّ، مكتبة

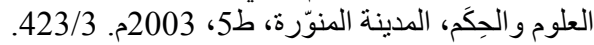

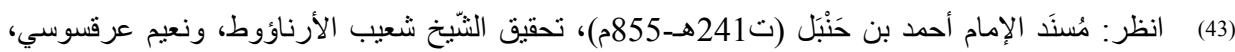

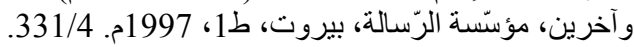

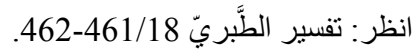




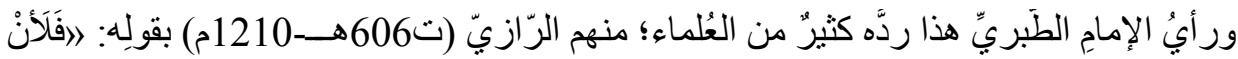

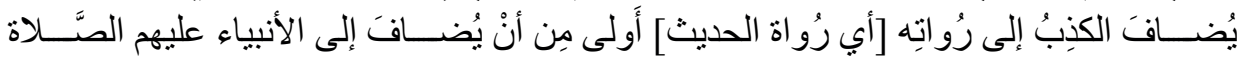

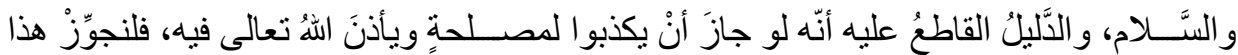

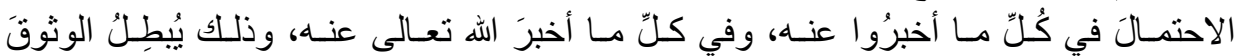

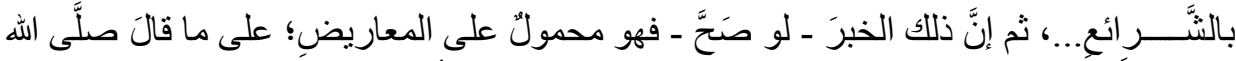

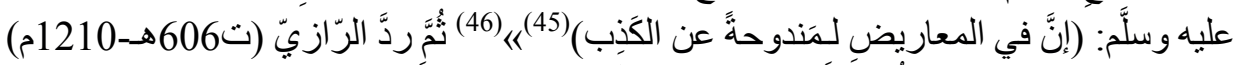

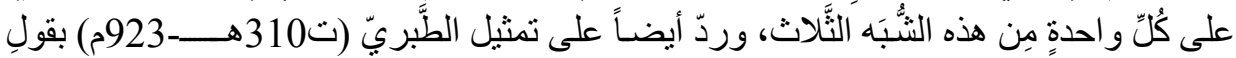

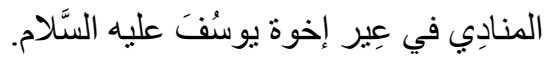

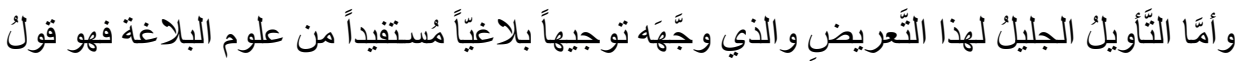

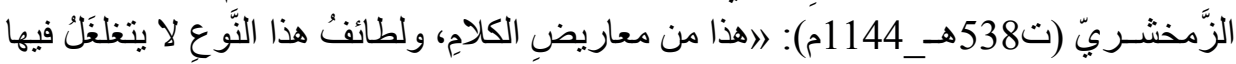

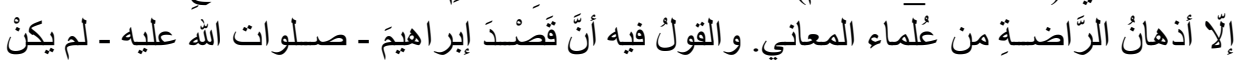

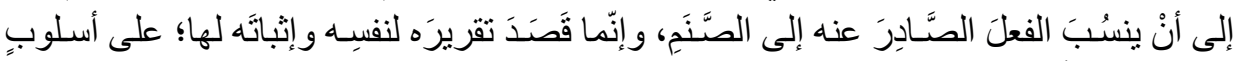

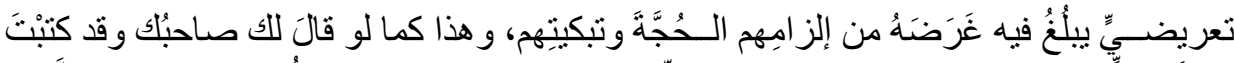

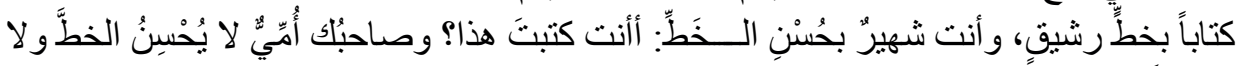

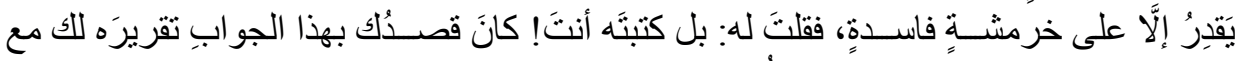

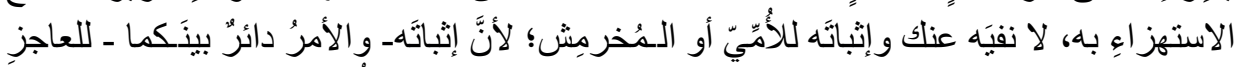

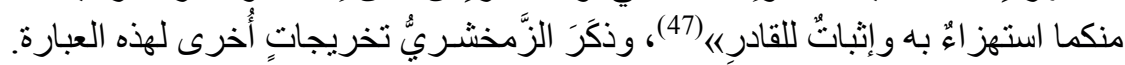

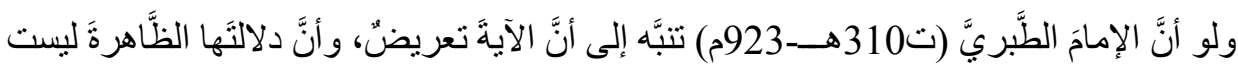

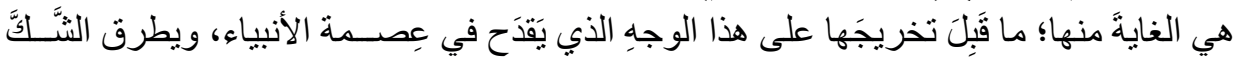

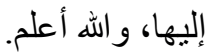

ولكن تردُد المفسِّــرين بين المعنيين الحقيقيّ و المجازيّ يدلُّ على أثرِ الفهم البلاغيّ في تفســيرِ

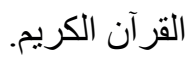

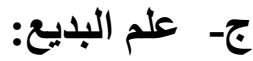

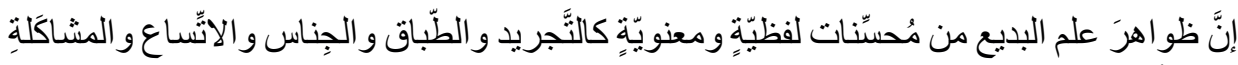

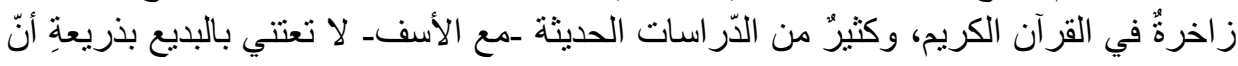

انظر : الأدب المفرد، البخاريّ (ت256هـ-870م)، تحقيق: محمّد فؤاد عبد الباقي، دار البشائر الإسلاميّة ـ-

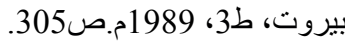
انظر : مفاتيح الغيب 156/22. 


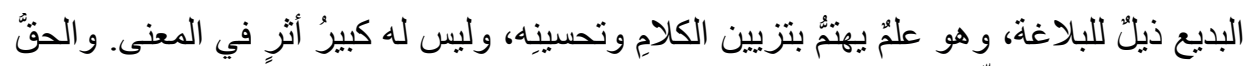

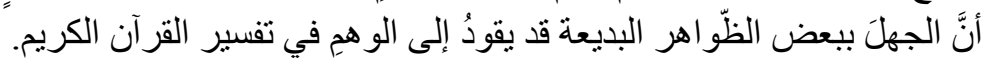

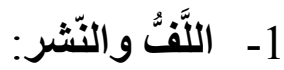

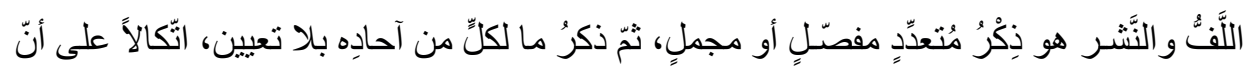

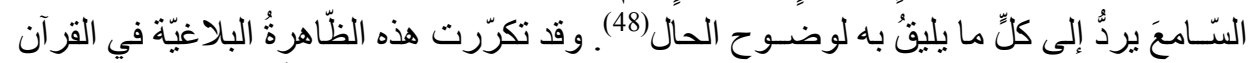

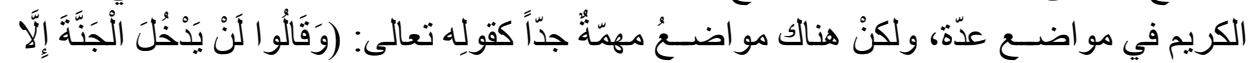

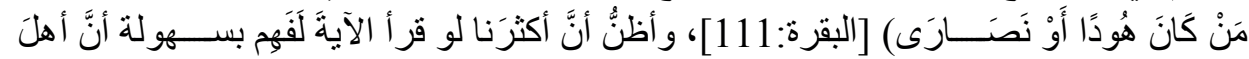

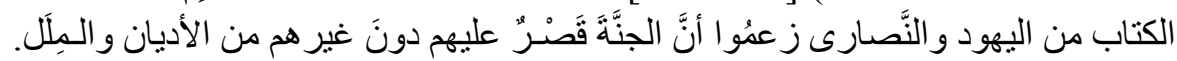

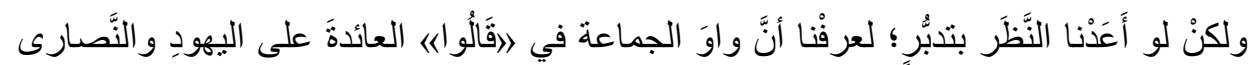

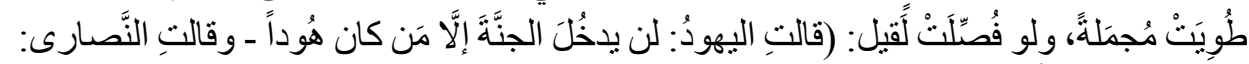

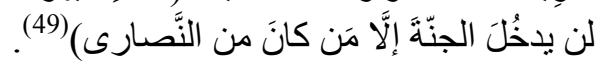

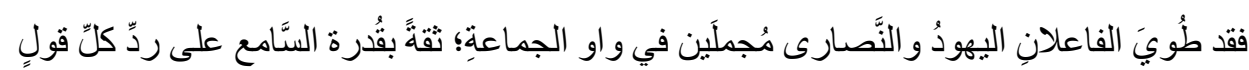

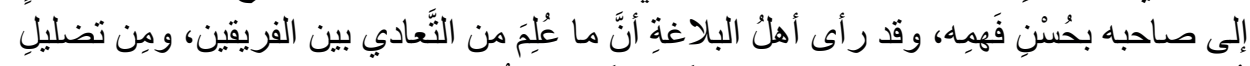

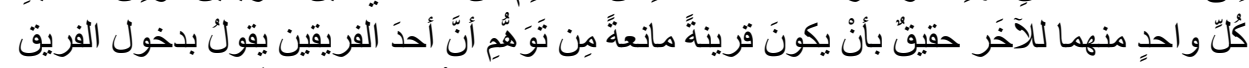

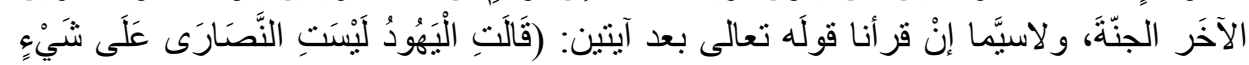

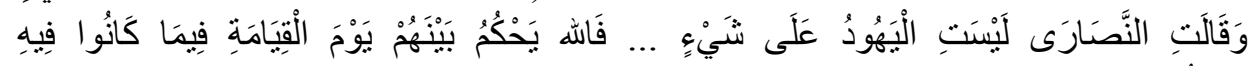

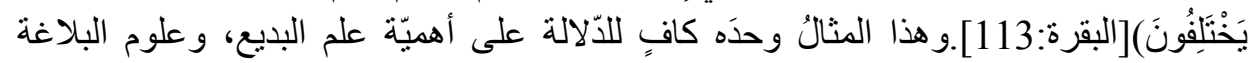
العربية في تفسير القرآن الكريم.

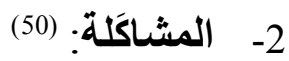

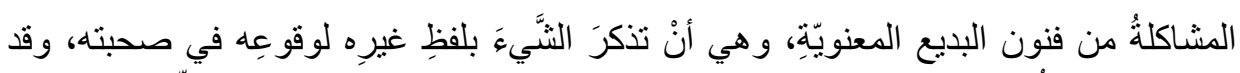

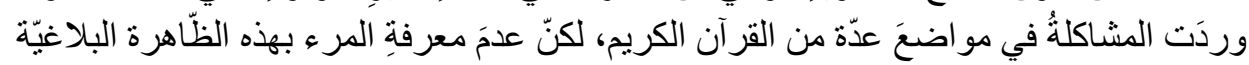

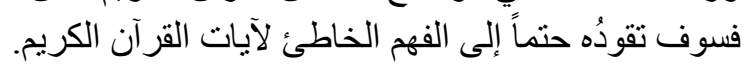

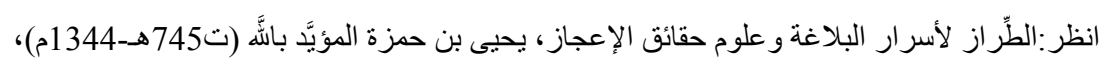

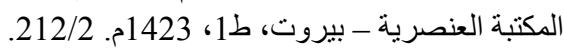

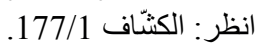

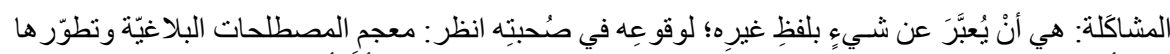

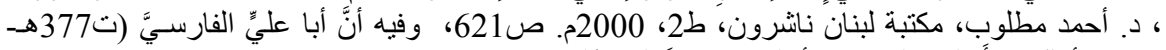
987م) أوّلُ من أُطلق على هذا الأسلوب تسميةً المشاكلَّة. 


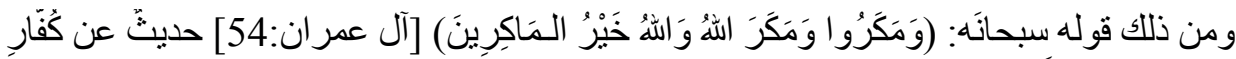

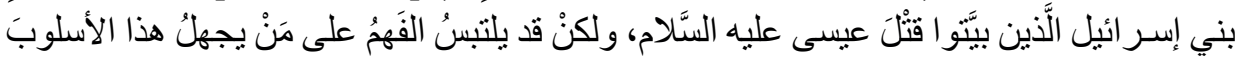

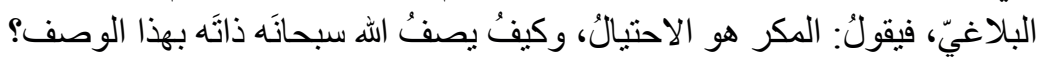

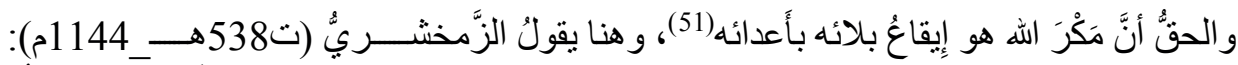

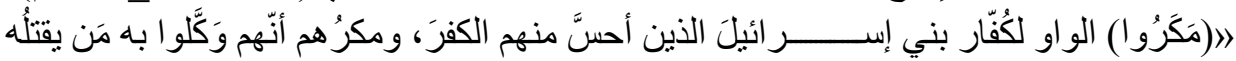

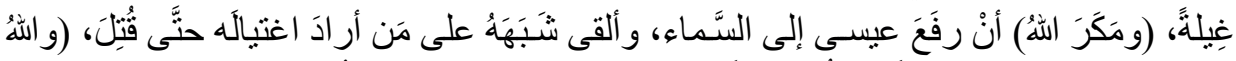

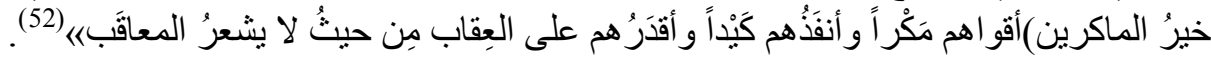

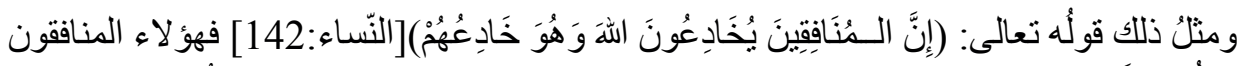

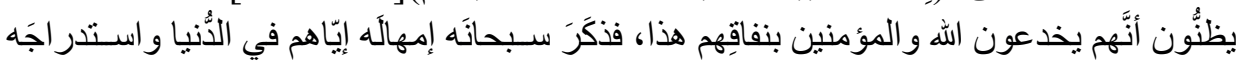
لهم بلفظٍِ(المخادَعة لهم) من باب المشاكلة.

فمَن لا يعرفُ أسلوب المشاكلة فسوف ينسب المكر و الخداع إلى الله سبحانَه، بسبب جهِله بأساليب البلاغة العربيّة.

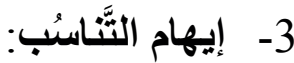

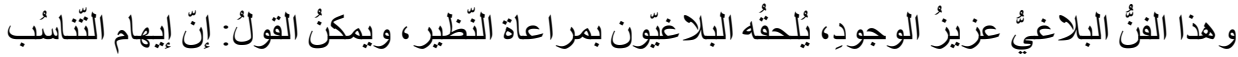

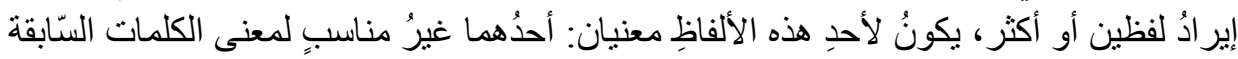

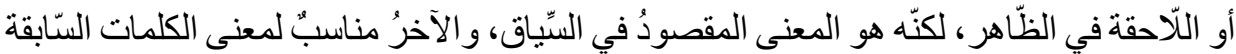

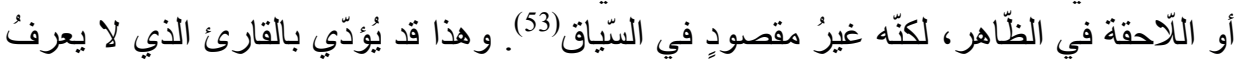
فنون بلاغة اللَّسان العربيّ إلى الو هم في الفهم.

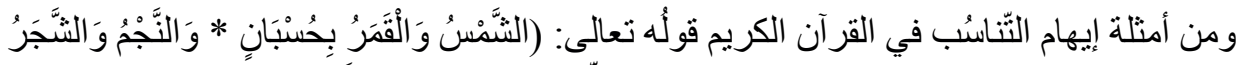

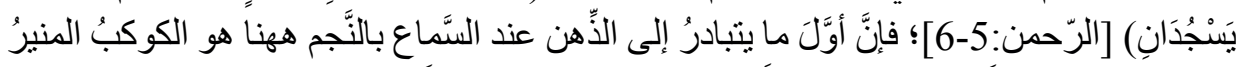

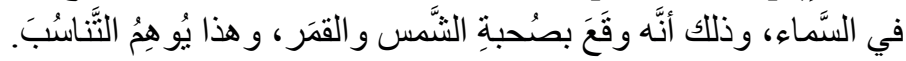

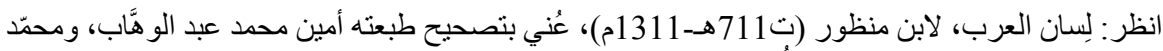
الصَّادق العبيديّ، ط3، دار إحياء الثُّراث العربيّ، بيروت، (د.ت). مادّة (مكر).

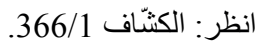

انظر : معجم المصطلحات البلاغيّة وتطوّر ها ص219. 


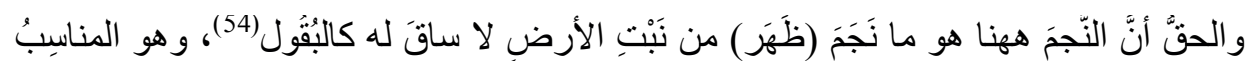

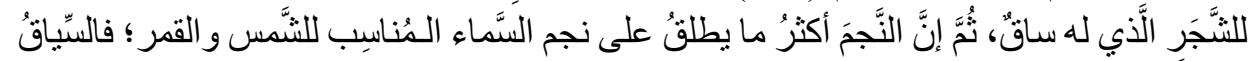

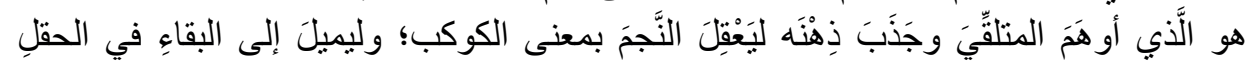
المعجميّ نفسِه.

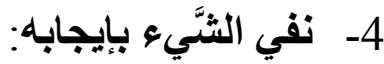

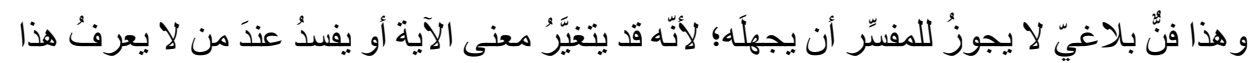

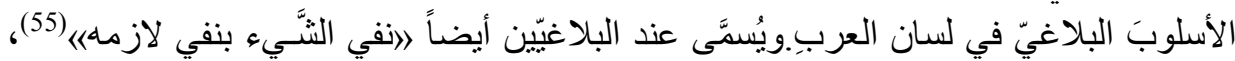

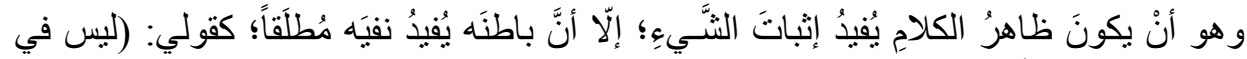

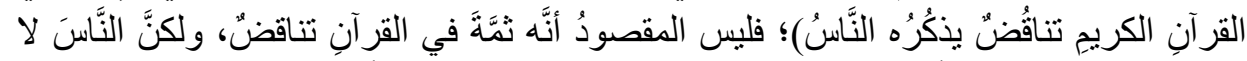

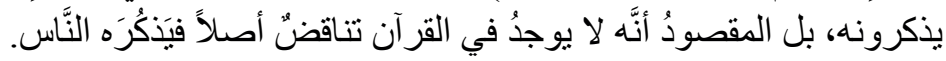

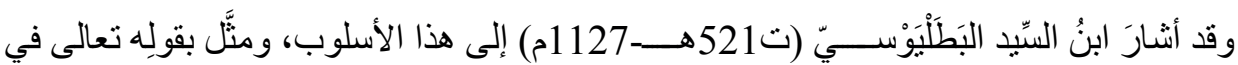

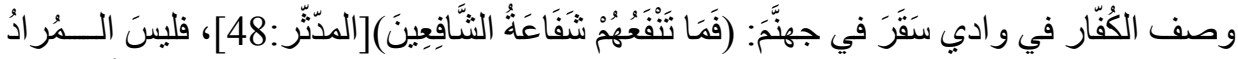

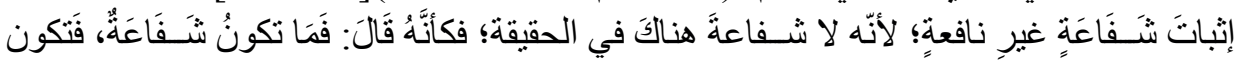

مَنْفَعَة (56)

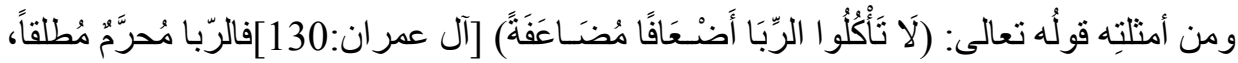

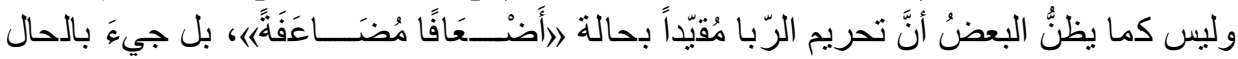

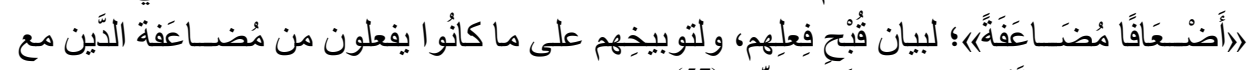

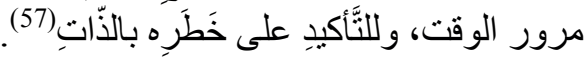

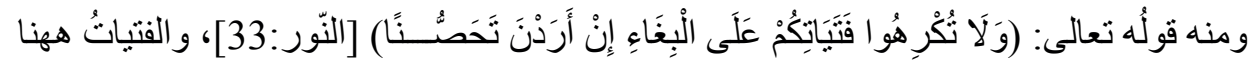

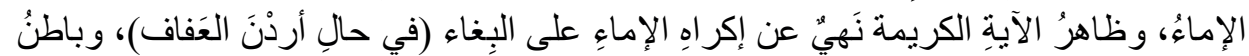

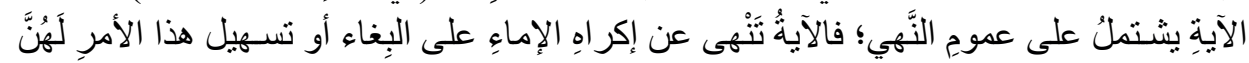

$$
\text { انظر : الكثّاف 443/4، ومفاتيح الغيب 339/29، وتفسير الجلالين ص532. }
$$

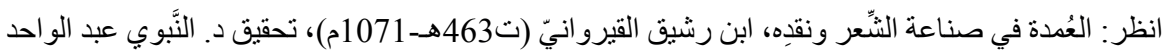

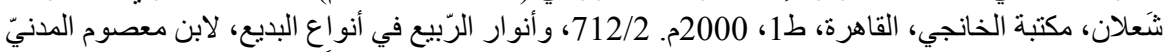

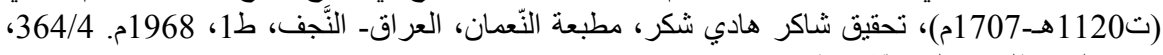

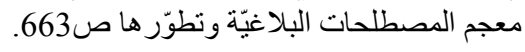

انظر : الإنصاف في التتبيه على المعاني و الأسباب التي أوجَبَت الاختلاف بين المسلمين في آرائهم، لابن السيّّدُ

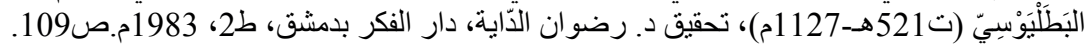




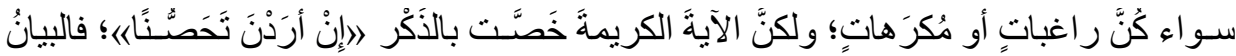

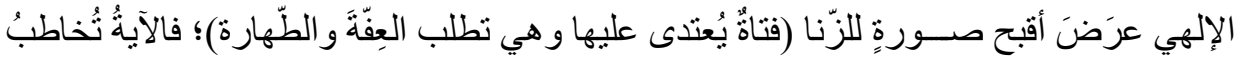

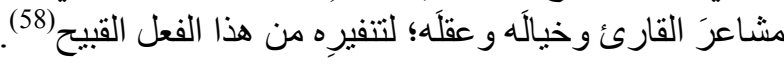

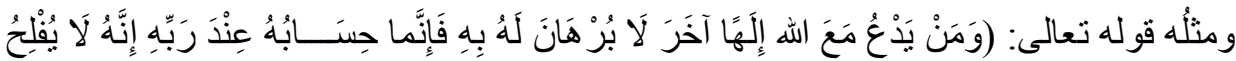

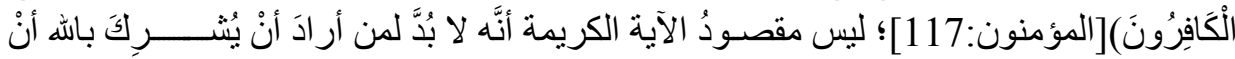

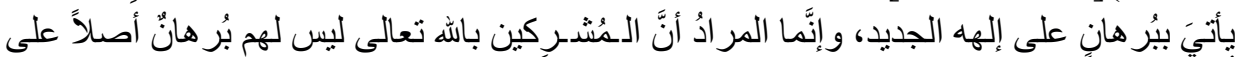

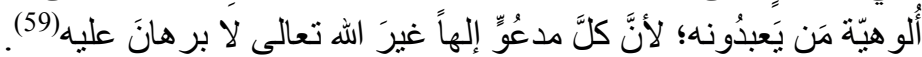

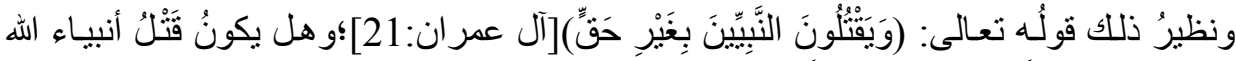

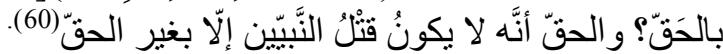

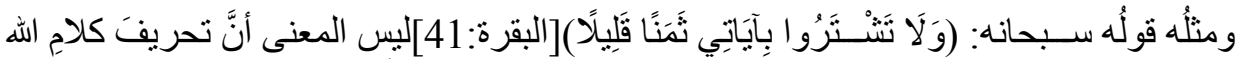

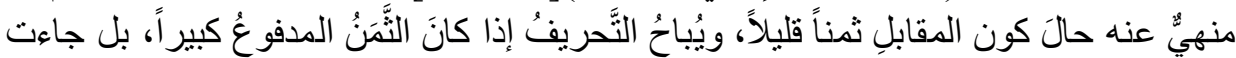

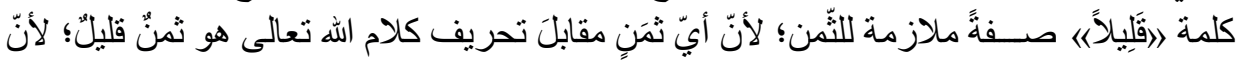

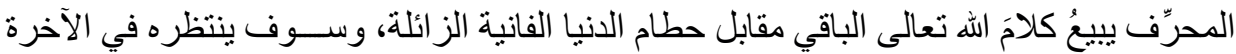
عذاب عظيم.

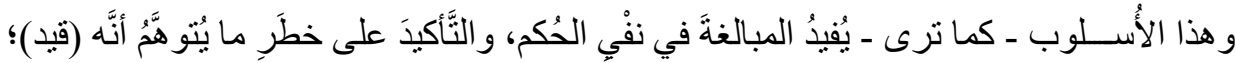

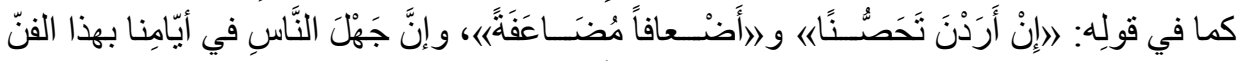

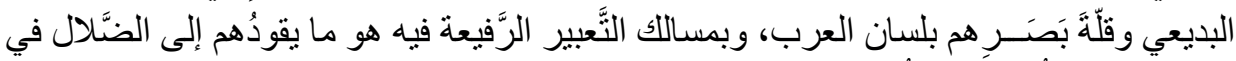

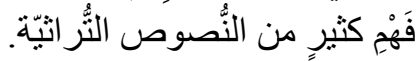

5- - 5ناسُب الأطر اف:

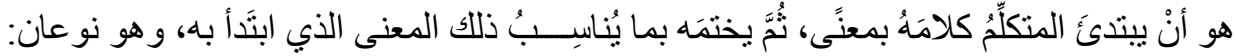

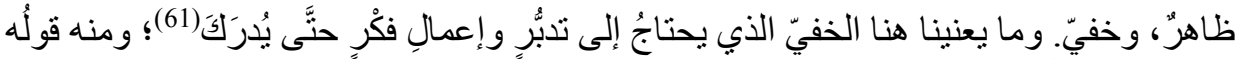

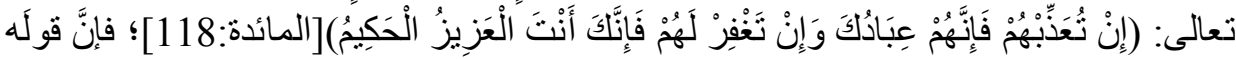

$$
\text { انظر: زاد المسير 458/1 (حاثية 1). }
$$

انظر : الانتصاف فيما تضمِنَه الكشّاف من الاعتز ال، (مطبوع على حاشية الكثَّف طبعة دار الفكر بيروت)

$.421 / 2$

انظر : التّحرير و التّوير 206/3. 


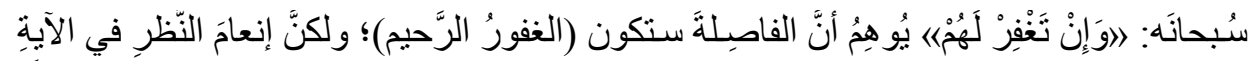

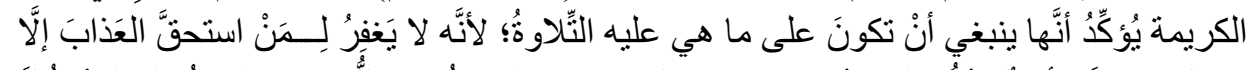

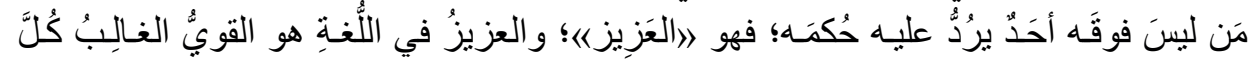

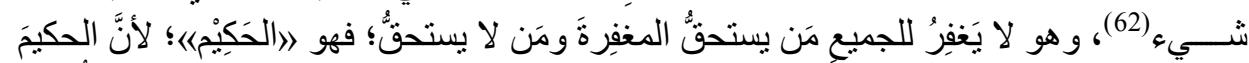

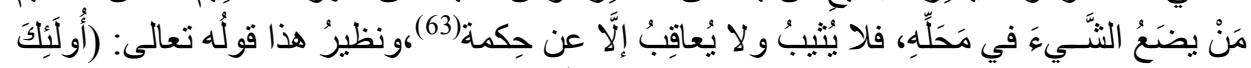

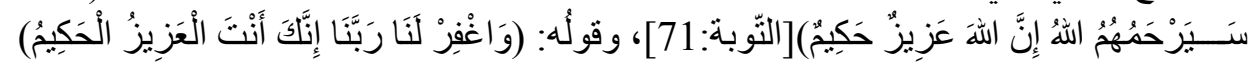

[الممتحنة:54)

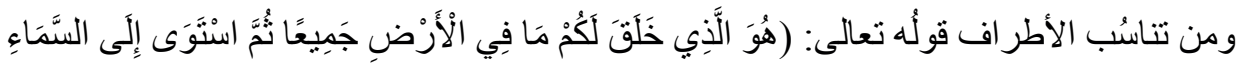

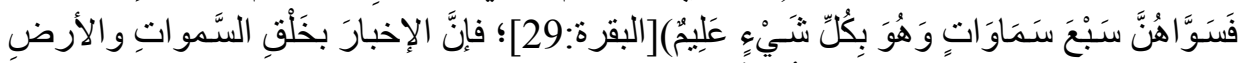

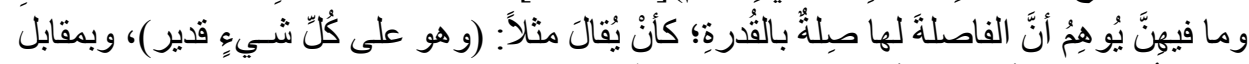

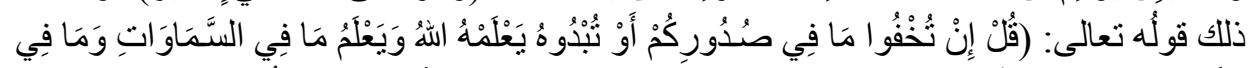

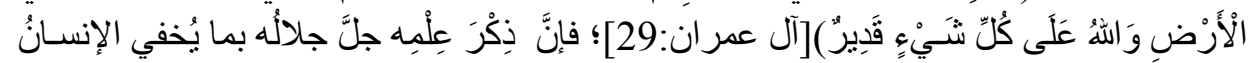

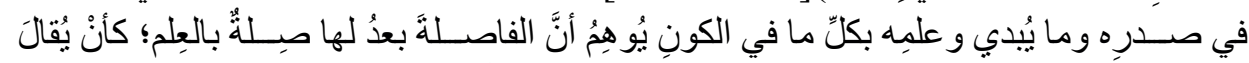

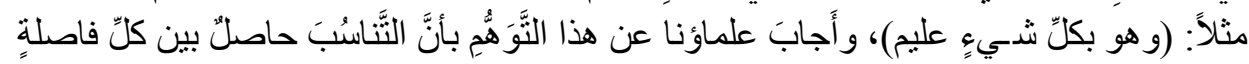

ومضمونِ آيتِها.

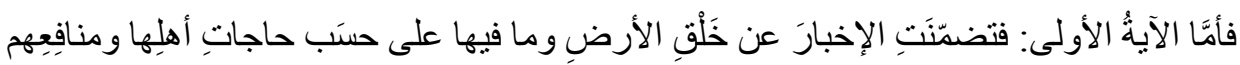

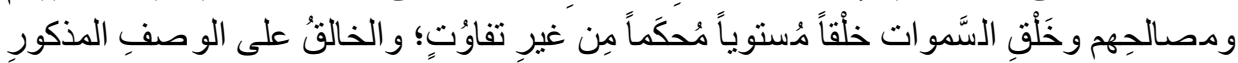

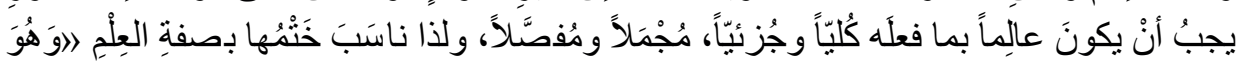

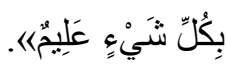

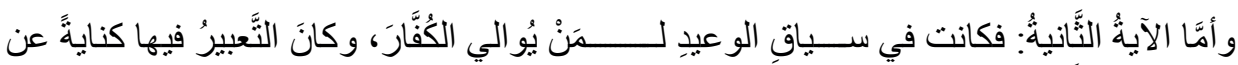

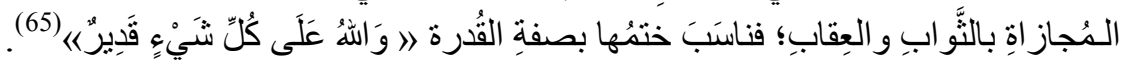

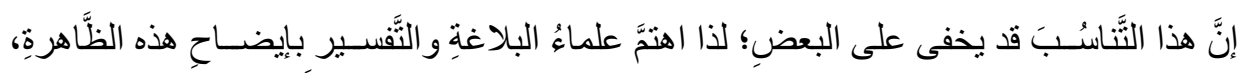

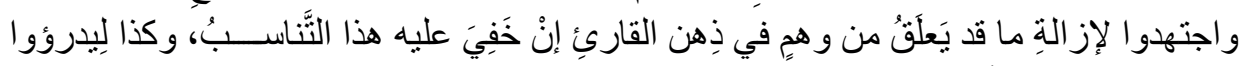

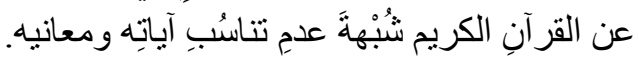




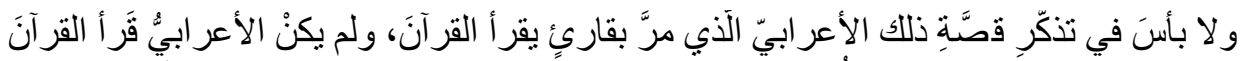

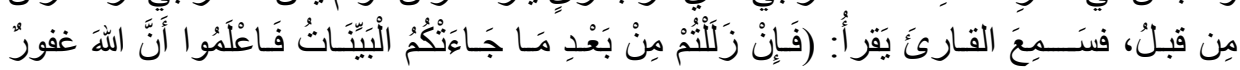

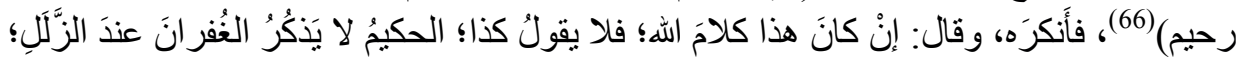

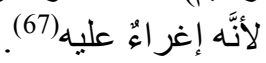

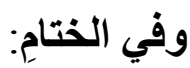

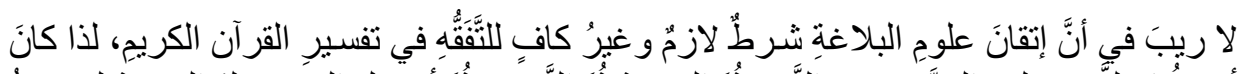

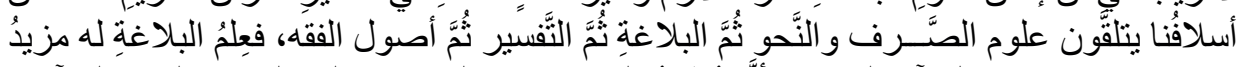

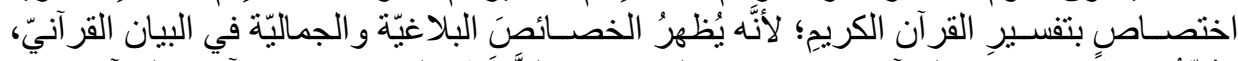

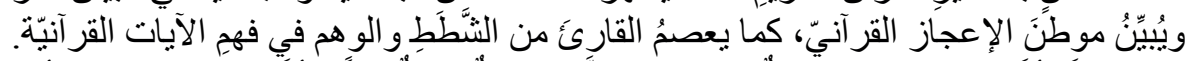

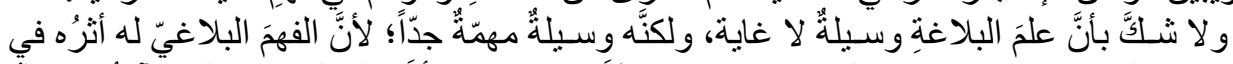

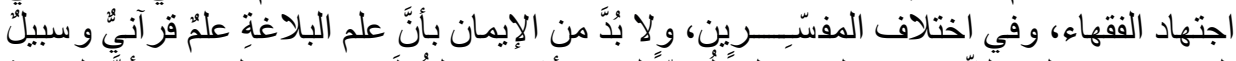

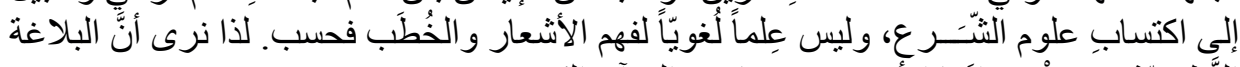

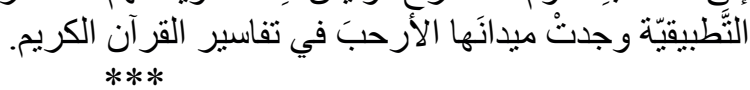

(") البقرة: 209. وصحَة الآية: (فاعلموا أنَّ اله عزيزّ حكيم). 


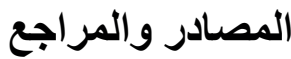

القرآن الكريم.

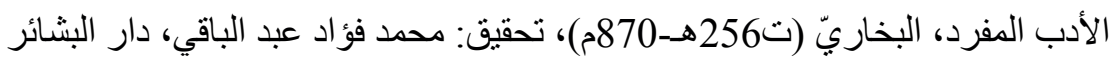
الإسلاميّة - بيروت، ط3، 1989م.

أسر ار البلاغة، الجرجانيّ (ت 471هـ-1078م)، تحقيق: محمود شاكر ، مطبعة المدني بالقاهرة، دار المدني بجدّة، ط1 البدة،

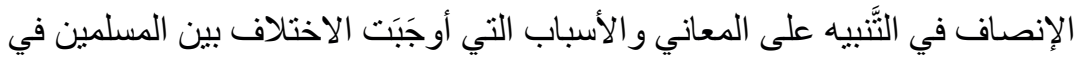

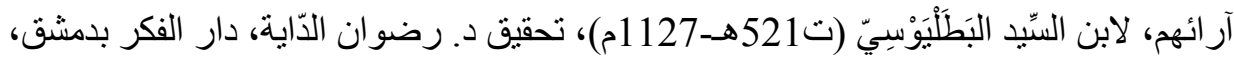
ط2، 1983م.

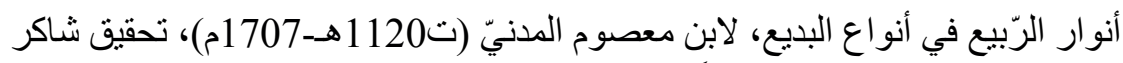

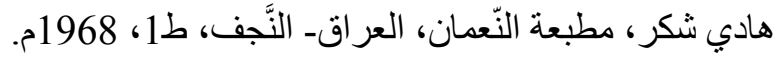

أيسر التفاسير لكلام العليّ الكبير، لجابر بن موسى بن عبد القادر بن جابر أبو بكر المكر

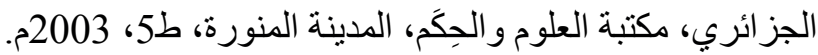

البرهان في علوم القرآن، الزركثي (ت794هـ-1392م)، تحقيق دار إحباء الكتب العربيّة

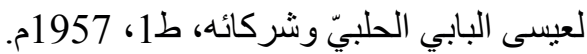

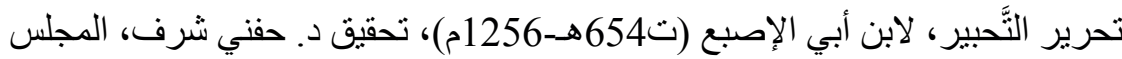

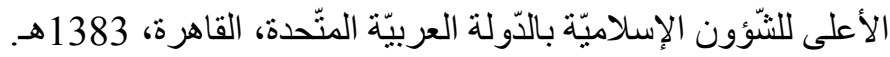

التَّدرير والتّنوير، الطّاهر بن عاشور (ت1393هـ-1973م)، الدّار التّونسية للنّشر ، تونس، 1984م.

تفسير أبي السّعود = إرشاد العقل السليم إلى مز ايا الكتاب الكريم، لأبي السُّعود العمادي

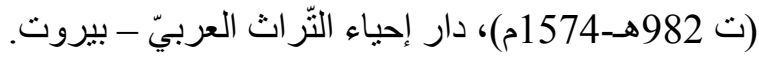

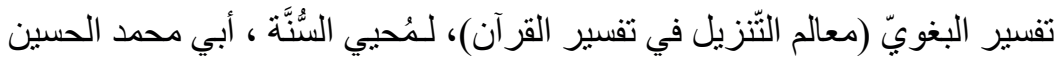

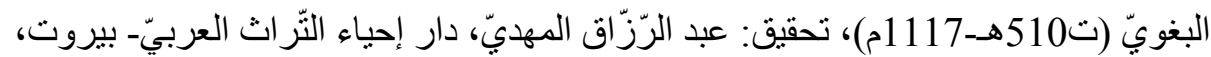




$$
\begin{aligned}
& \text { تفسير الجلالين، المحلَيّ (ت864هـ-1459م) و السيّيوطيّ (ت 911ه-1505م)، دار } \\
& \text { الحديث، القاهرة، ط1. }
\end{aligned}
$$

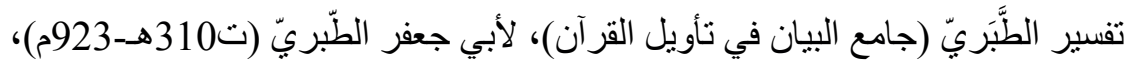

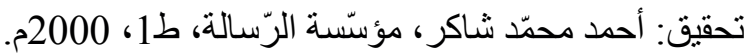

تفسير القرآن العظيم لابن أبي حاتم (ت327هـ-938م)، تحقيق: أسعد محمّد الطّيّب، مكتبة

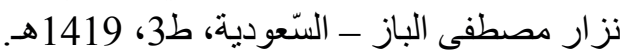

الحيَو ان، للجاحظ (ت255هـ-869م)، دار الكتب العلميّة ـ بيروت، ط2، 1424 هـ.

الخصائص، لابن جنّيّ (ت392 هـــ1002م)، تحقيق محمد علي نجّار ، الهيئة العامة

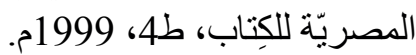

زاد المسير في علم التَّسبير، لابن الجَوزيّ (ت597هـ-1201م)، المكتب الإسلاميّ،

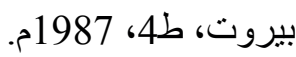

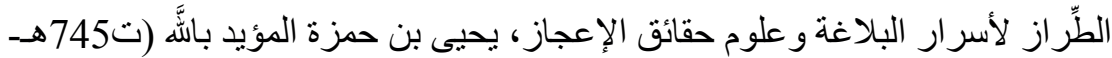

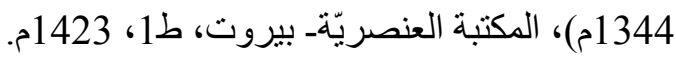

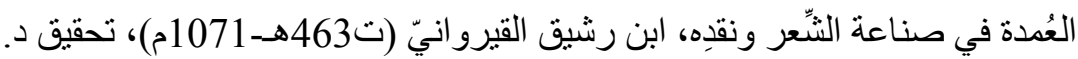

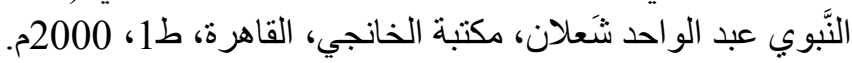
الكامل، للمبرِّد (ت285هـ- 898م)، تحقيق د. محمّد أحمد الدّالي، مؤسّسة الرّسالة، ط5، 2008

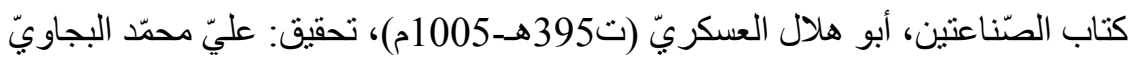

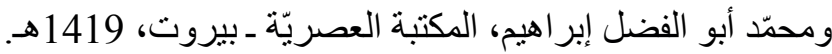

الكتاب، سييويه (ت180هـ-796م)، تحقيق: عبد السَّلام هارون، مكتبة الخانجي، القاهرة،

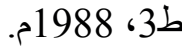

الكثّاف، الزَّمخشريّ (ت538هـ-1144م)، دار الكتاب العربي - بيروت، ط3،

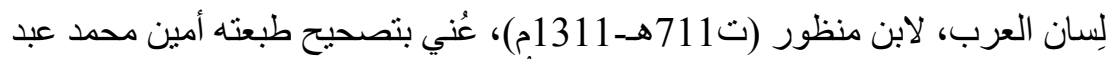

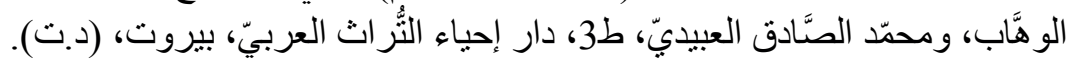




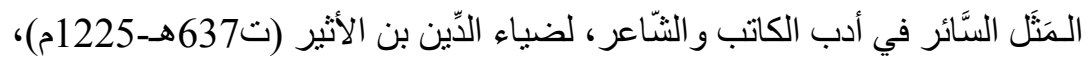

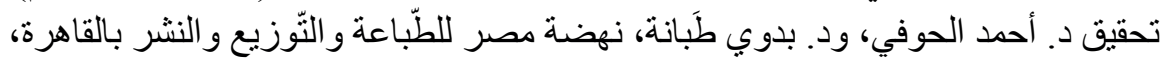

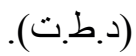

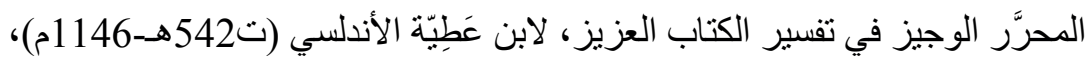

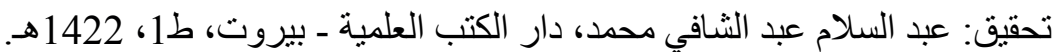

مُسنَّ الإمام أحمد ابن حَنْبَل (ت 241هـ-855ه)، تحقيق الثيخ شعيب الأرناؤوط، ونعيم

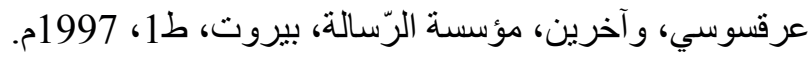

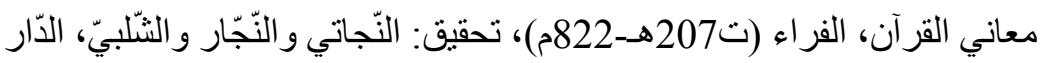

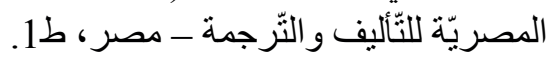

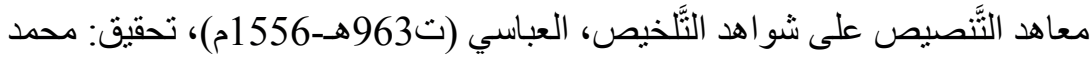

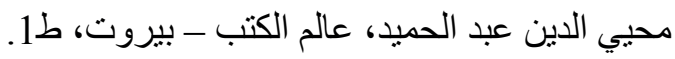

معجم المصطلَحات البلاغيّة وتطوّر ها، د. أحمد مطلوب، مكتبة لبنان ناشرون، ط2، 2000

مفاتيح الغيب ، لفخر الدّين الرّّازيّ (ت606هـ-140، 1210م)، دار إحياء التراث العربي،

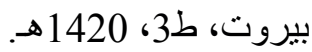

مفتاح العلوم، السّكّاكيّ (ت2626هـ-1229م)، تحقيق: نعيم زرزور، دار الكتب العلمية،

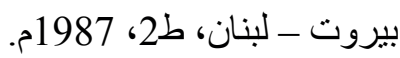

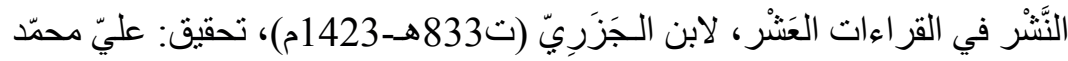

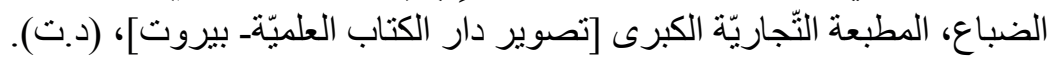

الهداية إلى بلوغ النّهاية في علم معاني القر آن وتفسيره، و أحكامه، وجمل من فنون

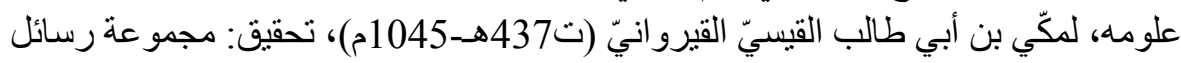

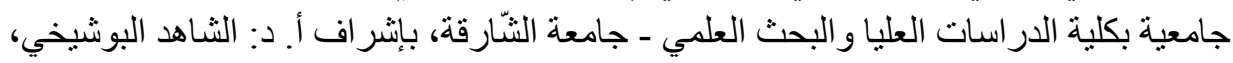

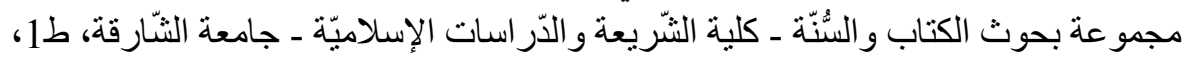
2008 
Abbâsî,Abdurrahîm b. Abdirrahmân b. Ahmed (ö. 963/1556), Me'âhidü 't-tensîs (thk. Muhammed MuhyiddînAbdülhamîd), Beyrut, ts. (Âlemü'l-kütüb).

Ahmed b. Hanbel (ö. 241(855), el-Müsned (thk. Şuayb el-Arnaût v. dğr.), Beyrut 1997.

Ahmed Matlûb,Mu 'cemü'l-mustalahâti'l-belâğlyyevetatavvuruhâ, Beyrut 2000 .

Begavî, Ebû Muhammed Muhyi’s-Sünne el-Hüseyin (ö.510/1117), Me âlimü t-Tenzîl (thk. Abdürrezzâk el-Mehdî), Beyrut 1420.

Buhârî, Muhammed b. İsmail (ö.256/870), el-Edebü'l-Müfred (thk. Muhammed Fuad Abdülbâkî), Beyrut 1989.

el-Câhız, Ebû Osman Amer b. Bahr el-Leysî (ö. 255/869), el-Hayevân, Beyrut 1424 .

Cürcânî,EbûBekirAbdülkahir b. Abdirrahman (ö. 471/1078), Esrâru'l-belâ$\breve{g} a$ (thk. Muhammed Şakir), Kahire-Cidde, Dâru'l-Medenî.

EbûBekir el-Cezâirî, Câbir b. Mûsâ b. Abdilkâdir, Eyseru't-tefâsîr li-Kelâmi'l-'Aliyyi'l-kebîr, Medîne-iMünevvere 2003.

EbûHilâl el-Askerî,el-Hasen b. Abdillâh b. Sehl el-Askerî (ö.395/1005), Kitâbü 's-Sinâ'ateyn (thk. Ali Muhammed el-Bicâvî-Muhammed Ebü'l-Fazl İbrahim), Beyrut 1419.

Ebussuûd Efendi (ö. 982/1574), İrşâdü'l- 'akli's-selîmilâmezâyâ'l-Kitâbi'lkerîm, Beyrut, ts. (Dâru İhyâi't-türâsi'l-'Arabî).

Fahruddîner-Râzî (ö. 606/1210), Mefâtîhu'l-gayb, Beyrut 1420.

Ferrâ',EbûZekeriyyâYahyâ b. Ziyâd b. Abdillâh el-Absî (ö.207/822), Me 'âni'l-Kur'ân (thk. en-Necâti / en-Neccâr / eş-Şelebî), Kahire, ts. (ed-Dâru'l-Misriyye).

İbn Âşûr, Muhammed b. et-Tâhir (ö. 1393/1973), et-Tahrîrve't-tenvîr, Tunis 1984.

İbn Atıyye el-Endelüsî,Ebû Muhammed Abdülhak b. Gâlib b. Abdirrahmân el-Girnâtî (ö. 542/1146), el-Murraru'l-vecîz (th.AbdüsselâmAbdüşşâfî), Beyrut 1422 .

İbn Cinnî,Ebü'l-Feth Osman el-Mevs1lî el-Bağdâdî (ö. 392/1002), el-Hasâis (thk. Muhammed Ali en-Necâr), Kahire 1999.

İbn EbîHâtim, EbûMuhamed Abdurrahman b. Muhammed (ö. 327/938), Tefsîru'l-Kur'âni'l- 'azîm (thk. Es'ad Muhammed et-Tayyib), Mekke 1419. 
İbn Ebi'l-İsba',Ebû Muhammed ZekiyyüddînAbdül'azîm el-Misrî (ö. 654/1256), Tahrîru't-Tahbîr (thk. HıfnîŞeref), Kahire 1383.

İbn Ma'sûm el-Medenî (ö.1120/1707), Envâru'-rabî‘ fìenvâi’l-bedî̀ (nşr. ŞakirHâdîŞâkir), Necef 1968.

İbn Manzûr,Ebü'l-FazlCemâlüddîn Muhammed b. Mükerrem el-Ensârî (ö. 711/1311), Lisânü'l- 'Arab, Beyrut, ts. (Dâru İhyâi't-türâsi'1-'Arabî).

İbn Reşîk el-Kayrevânî,Ebû Ali el-Hasan (ö. 463/1071), el- 'Umdefîsınâ'ati 'ş-şi 'rvenakdih (thk. En-NebevîAbdülvâhidŞa 'lân), Kahire 2000.

İbn Sîde el-Batalyevsî (ö. 521/1127), el-İnsâffi't-tenbîh (thk. Rıdvaned-Dâye), Dımaşk 1983.

İbnü’1-Cevzî,Ebü’l-FerecCemâlüddîn Abdurrahman b. Ali (ö.597/1201), Zâdü'l-mesîrfì 'ilmi t-tefsîr, Beyrut 1987.

İbnü'l-Cezerî,Ebü'l-Hayr Muhammed b. Muhammed ed-Dımaşkî (ö.833/1423), en-Neşrfí kurââti'l- 'aşr (thk. Ali Muhammed ed-Dabbâ'), Beyrut, ts. (Dâru'l-Kütübi'l-ilmiyye, ofset).

İbnü'l-Esîr,Ziyâüddîn (ö. 637/1225), el-Meselü 's-sâirfièedebi'l-kâtibve'ş-şấ 'ir (thk. Ahmed el-Hûfî-BedevîTabâne), Kahire, ts. (NahdatüMısr).

el-Mahallî (ö. 864/1459)-es-Süyûtî (ö.911/1505), Tefsîru'l-Celâleyn, Kahire, ts. (Dâru'l-Hadîs).

Mekkî b. EbîTâlib,Ebû Muhammed Mekkî b. EbîTâlibHammûş b. Muhammed el-Kaysî (ö. 437/1045), el-Hidâyeilâbulûgı'n-nihâye (thk. eş-Şâhid el-B3uşeyhî başkanlığındabirheyet), Şârika 2008.

el-Müberrid,Ebü'l-Abbâs Muhammed b. Yezîd (. 285/898), el-Kâmil (nşr. Muhammed Ahmed ed-Dâlî), Kahire 2008.

Sekkâkî,EbûYa'kûbSirâcüddînYûsuf el-Hârizmî (ö. 626/1229), Miftâhu'l'ulûm (thk. NuaymZarzûr), Beyrut 1987.

Sîbeveyhî,EbûBişr Amr b. Osmân b. Kanber el-Hârisî (ö. 180/796), el-Kitâb (thk. Abdüsselâm M. Hârûn), Kahire 1988.

Taberî,EbûCa'fer Muhammed b. Cerîr (ö. 310/923), Câmi 'u'l-beyân (nşr. Ahmed Muhammed Şâkir), Kahire 2000.

Trablusî,Şemsüddîn Muhammed b. Mahmûd (ö.), Dürerü'l-ferâidi'l-müstahsenefîserhiManzûmeti İbn Şihne (thk. SüleymanHüseyin el-Umeyrat), Yükseklisanstezi, DımaşkÜniversitesi, 2010.

el-'Umeyrât,SüleymanHüseyin, el-Îhâmü'l-belâğ̂̂ $\quad$ (Şi 'ruEbîTemmâmve'l-Buhturîenmûzecen), doktoratezi,DımaşkÜniversitesi 2013. 
Yahya b. Hamza el-MüeyyedBillah (ö.745/1344), et-Tirâz li-esrâri’lbelâğave 'ulûmihakâikı'l-i'câz, Beyrut 1423.

Zemahşerî,Ebü'l-KâsımCârullahMahmûd b. Ömer el-Hârizmî (ö. 538/1144), el-Keş̧̧âf, Beyrut 1407.

Zerkeşî, Bedruddîn Muhammed b. Abdillah (ö. 794/1392), el-Burhânfî 'ulûmi'kl-Kur'ân, Kahire 1957. 